\title{
The physical, physiological, and biological effects of qigong therapy
}

\author{
XinQi Dong ${ }^{1 *}$, E-Shien Chang ${ }^{1}$ and Kevin Chen ${ }^{2}$ \\ ${ }^{1}$ Rush University Medical Center, Chicago, Illinois, USA \\ ${ }^{2}$ University of Maryland, School of Medicine, Maryland, USA
}

\begin{abstract}
Qigong is a Chinese traditional practice that has been developed for thousands of years. One of its purposes is to improve and sustain health. Research has also shown that Qigong is effective in improving many health outcomes. Many research gaps exist, especially concerning study design and investigations into the physiological and biological effects of Qigong practice. To fill in the knowledge void, this review focuses on the state of qigong research regarding its physical, physiological, and biological effects. Our findings suggest that far-infrared, bio magnetic, and neurological applications are common measurements in understanding the physical effects of Qigong. Heart rate variations, pulse, and blood pressure changes are also commonly used in measuring physiological effects of Qigong. Last, biological effects of Qigong may include biochemical parameters, glucose, and immune parameters, among others. More methodological rigorous research exploring the particular physiological and biological pathway of Qigong practice and health outcomes is needed. Future research should also closely examine the feasibility and adaptability of Qigong therapy while evaluating the effects of Qigong versus other forms of mind-body exercise. Last, researchers, health providers and community leaders should investigate and improve the physical and psychosocial health and health behaviors of minority populations through culturally appropriate and adaptable exercises like Qigong.
\end{abstract}

\section{Background}

Qigong is an increasingly popular modality of traditional Chinese medicine (TCM) believed to be over 4,000 years old [1]. Written records referring to Qi (vital energy) and its effects are thought to be as old as 3,300 years. Qigong exercise is based on the traditional Chinese belief and Taoist philosophy that human body contains a network of energy pathways through which vital energy circulate. As a mind-body practice in Energy Medicine, Qigong aims to achieve a harmonious flow of vital energy in the body and regulate the functional activities of the body through regulated breathing, mindful meditation, and gentle movements [2].

Qigong is a mind-body practice that uses breathing adjustment, body postures and/or mindful meditation to harmonize the body, mind, and spirit. Its main theory is that discomfort, pain, and sickness are a result of energy; that is, if there is a free flow of energy (Qi) and a balance of energy (Qi) in the energy channel, health can be improved, maintained and disease prevented. Blocked Qi was considered to be the original of many illnesses and diseases [3].

In the past decade, a growing number of studies globally have critically evaluated the effectiveness of qigong exercise in physical, mental and cognitive health improvement. Existing systematic reviews and meta-analyses examined the clinical evidence of the beneficial effects of qigong on different medical conditions, including cancer [47], cardiopulmonary diseases [8,9], hypertension [10-12], infectious deceases [13]; movement disorder [14,15] and fibromyalgia [16]. Other reviews also examined the overall effectiveness of qigong on chronic condition management including diabetes [17] and pain management [18]. Several recently published systematic reviews further provided evidence on the effectiveness of Qigong exercises on reducing psychological distress including depressive symptoms, anxiety symptoms $[19,20]$.

Whereas health effects of Qigong practice have been addressed in the current medical and public health literature, few reviews have systematically evaluated the key components of Qigong biofields that are closely associated with its healing effects, except two review articles published about ten years ago $[21,22]$. Researchers in complementary and alternative medicine (CAM) continue to have different conceptualization in ways to measure Qi. Chen et al proposed that if there was bioenergy, then it should be detectable and measurable by physical instruments or biomarkers [23]. Others argued that bioenergy also exists in the forms of electrical, magnetic, and/or electromagnetic substance in nature and that it's transmission and reception would interact at the cellular and molecular levels [24]. However, to date, the concept of Qi bioenergy has not been well-articulated. This research gap points to the ongoing methodological challenges in Qigong therapy research; mainly, knowing what is to be measured, what could be measured, and finding appropriate technologies and measurements to properly develop the approaches and instrumentation associated with the practice of Qigong [25,26].

In light of the limitations of previous reviews, and the high demand

Correspondence to: XinQi Dong, Director, Chinese Health, Aging and Policy Program, Associate Director, Rush Institute for Health Aging, 1645 West Jackson, Suite 675, Chicago, IL 60612, USA, Tel: 312942 3350; Fax: 312942 2861; E-mail: xinqi_dong@rush.edu

Key words: Qi-training, complementary and alternative medicine, traditional Chinese medicine

Received: April 17, 2016; Accepted: May 11, 2016; Published: May 16, 2016 
for more understanding of Qigong therapy, the purpose of this review paper is to address critical measurement issues pertaining to Qigong research. The aims of this review are to understand 1) the physical and biological detector measurement of Qigong; 2) the physiological detectors of Qigong; 3) research gaps in and implications of the practice of Qigong and its impact on the health of the global populations.

\section{Methods}

The study design was developed in accordance with the Preferred Reporting Items for Systematic Reviews and Meta-Analyses (PRISMA) guidelines. Studies eligible for inclusion were papers assessing the biological, physical, chemical, and physiological detectors of Qi in Qigong studies. The search keywords included the following: Qigong, Qi therapy, Qi training, Qi practice, Chi-Kung bioenergy Qi detectors. Due to the scope of this research intended to focus on Qigong specifically, we did not include search terms in other forms of therapies such as Reiki or other energy-training methods. Two investigators independently reviewed the manuscripts identified by the search methods and selected qualified studies according to the content, criterion and construct validity.

The literature search was conducted online using both medical and social science databases, including MEDLINE, PubMed, PsychInfo, China journals full-text database (www.cnki.net), Wan Fang data and Google Scholar. The search was limited to studies available in full-text, and written either in English or in Chinese, and published between 1990 and 2015. Exclusion criteria included using life sensors as detectors, or using human body or animals as detectors, laboratory tests on cultured plates or treat enzyme samples, conference proceedings, unpublished manuscripts, school term reports, or no data reported. Full search methodology for publications is shown in Figure 1.

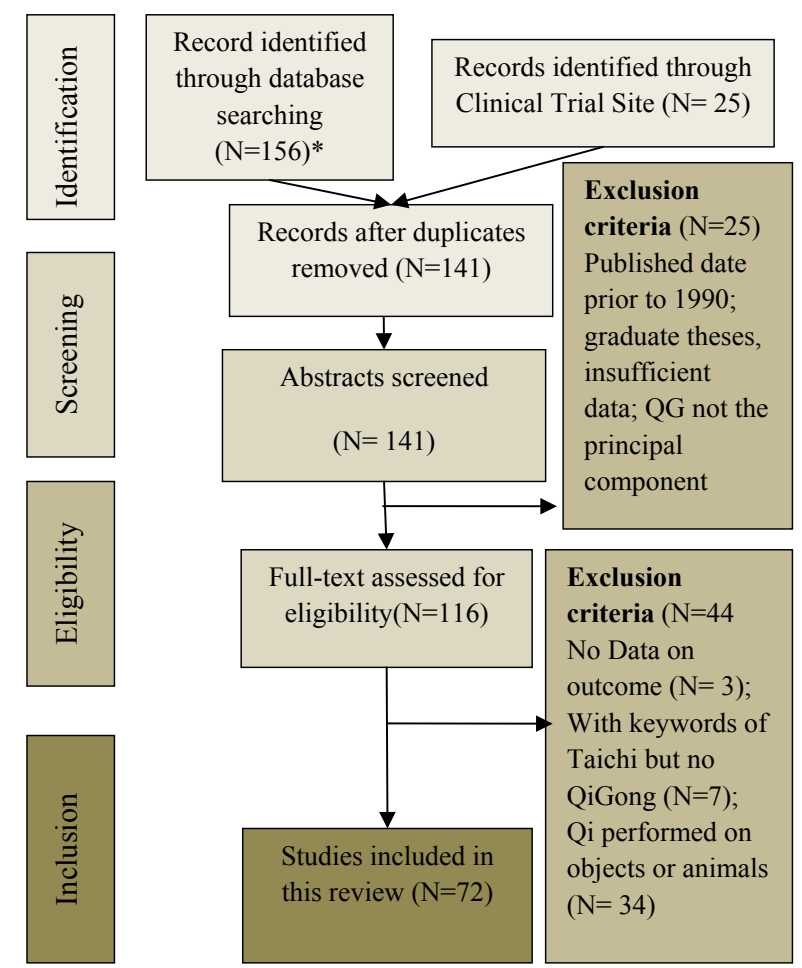

*Key words: Qigong, Qi therapy, Qi training, Qi practice, bioenergy Qi detectors

Figure 1. Literature Selection Flow Chart.

\section{Results}

Our search yielded 59 English-language results and 13 Chineselanguage results; the major methods for measuring or evaluating Qigong effects can be classified into the following three categories of detector: 1) physical signal detectors; 2) physiological dynamics methods; 3 ) biological materials as detectors.

\section{Physical signal detectors}

Physical detectors are the primary methods that most researchers have used as they fit into the traditional energy assessment model (Table 1) [22]. Such studies typically assess heat, magnetism, electricity, or radiation. Many other exploratory studies of external Qigong effects have used various physical detectors, including Gamma ray, microwave, and high-frequency X-ray. Body temperature changes before, during, and after the practice of Qigong have been documented by many empirical studies [27-29], in which far-infrared measurement was amongst the most commonly used physical detectors of Qi [21]. A few studies tested with far-infrared thermography demonstrated the significant temperature change on the body surface with infrared detectors during both self-qigong practices or with a qigong healer. Working with Spanish children aged between 10-12, Matos et al. [30] showed that there were statistically significant changes in temperature measured by thermography occurred during the exercises and at the beginning and at the endpoint of the observation interval $(p<0.001)$, and effects remain stable after weeks of training. Through direct observation, Lo et al. [27] reported significant changes in the maximum temperature measured by infrared images in body surface temperature including front, back and face regions. However, current far and infrared findings are predominantly limited in Chinese literature, and most focused on directly observing the external Qi dissipated from Qigong masters rather than recording the flow of Qi per se [21].

Biomagnetic is another commonly used application to measure healing effects. The application of magnetic field is a widely used ancient healing technique around the world. Previous studies in therapeutic touch suggested that the 8 - to $10-\mathrm{Hz}$ frequency band may be associated with emission from the human biofield during therapeutic interventions [31,32]. Similarly, in an observational Qigong study conducted in Japan, Hisamitsu [33] found that the 8-12 Hz frequency band was emitted when participants performed breathing techniques. This study finding suggested that Qigong breathing appeared to stimulate a large biomagnetic field emission similar to other alternative therapies.

Brain change associated with Qigong has been central in scholarly inquires. Due to its high costs, few studies have thus far investigated functional-MRI changes in large-scale studies. Current available f-MRI studies with Qigong masters suggested that the response amplitude of the SII-insula region under the state of Qigong (3.5\%) was greater than that before Qigong (1.2\%) [34]. Another observation study in China reported significant frontal lobe and left temporal lobe changes $(\mathrm{p}<0.05)$ under Qigong stimulation state [35]. After a short-term meditation training, MRI images showed increased brain connectivity in the anterior cingulated, suggesting that Qigong meditation might have the potential to rewire neurons in the brain and rebuild connections among neurotransmitters. However, limited study to date has included f-MRI scans before and after Qi practice with a large sample of layman practitioners.

In addition to neuroimaging techniques such as f-MRI, EEG and 


\begin{tabular}{|c|c|c|c|c|c|c|c|c|c|c|}
\hline \multirow[t]{2}{*}{ Author, Year } & \multirow{2}{*}{$\begin{array}{l}\text { Study } \\
\text { Design }\end{array}$} & \multicolumn{6}{|c|}{ Population Characteristics } & \multirow{2}{*}{ Methods } & \multirow[t]{2}{*}{ Outcome of Interests } & \multirow[t]{2}{*}{ Main Findings } \\
\hline & & \# & Country & Age & Sex & $\begin{array}{l}\text { Previous } \\
\text { QG } \\
\text { Practice }\end{array}$ & $\begin{array}{l}\text { Type of } \\
\text { QG }\end{array}$ & & & \\
\hline \multicolumn{11}{|c|}{ Far-Infrared Measurement } \\
\hline $\begin{array}{l}\text { Matos et al., } \\
2015[30]\end{array}$ & OS & 7 & Europe & $10-12$ & $6 \mathrm{~F} 1 \mathrm{M}$ & None & WB & $\begin{array}{l}\text { A prospective study of } \\
\text { participants with no experience } \\
\text { as baseline data, and after QG } \\
\text { practice as intervention data. }\end{array}$ & $\begin{array}{l}\text { To examine the effects } \\
\text { of QG exercises by } \\
\text { thermography of the hands } \\
\text { prior to and after a seven- } \\
\text { week QG training program }\end{array}$ & $\begin{array}{l}\text { Statistically significant changes in } \\
\text { temperature measured by thermography } \\
\text { occurred during the exercises and at } \\
\text { the beginning and the endpoint of the } \\
\text { observation interval }(\mathrm{p}<0.01) \text {. Heart rate } \\
\text { results point to a significant decrease in } \\
\text { the QG program, the mean heart rate } \\
\text { at the beginning of the program was } \\
102.9 \text { beats per minute, with a standard } \\
\text { deviation of } 20.5 \text { beats per minute and at } \\
\text { the end these values were } 92.0 \text { and } 17.2 \text {, } \\
\text { respectively. }\end{array}$ \\
\hline $\begin{array}{l}\text { Lo et al., } \\
2007[27]\end{array}$ & OS & 1 & U.S. & NR & NR & NR & NR & $\begin{array}{l}\text { A male patient with car accident } \\
\text { was treated with external Qi (no } \\
\text { touch) over } 3 \text { month period. }\end{array}$ & $\begin{array}{l}\text { To document infrared } \\
\text { images of change in body } \\
\text { surface temperature. }\end{array}$ & $\begin{array}{l}\text { Significant changes in the maximum } \\
\text { temperature were reported in some parts } \\
\text { of the body before and after healing. } \\
\text { The largest differences were } 6.7^{\circ} \mathrm{F} \text { in the } \\
\text { back region }(97.87 \text { to } 91.17), 1.14^{\circ} \mathrm{F} \text { in } \\
\text { the lower back region }(96.26 \text { to } 85.12) \text {, } \\
0.97^{\circ} \mathrm{F} \text { in the front region }(97.33 \text { to } \\
96.36), 3.83^{\circ} \mathrm{F} \text { in the upper back region } \\
(101.97 \text { to } 98.14) \text {, and } 2.11^{\circ} \mathrm{F} \text { in the face } \\
(101.11 \text { to } 99) \text {. }\end{array}$ \\
\hline \multicolumn{11}{|c|}{ Biomagnetic Measurement } \\
\hline $\begin{array}{l}\text { Shin et al., } \\
2003 \text { [73] }\end{array}$ & OS & 11 & Korea & $10-17$ & NA & None & NR & $\begin{array}{l}\text { Observational study of students } \\
\text { who put hands in front of the } \\
\text { sensors and emitted Qi from } \\
\text { the palms to be measured by } \\
\text { magnetometers. }\end{array}$ & $\begin{array}{l}\text { To measure the bio-magnetic } \\
\text { field emitting from palm } \\
\text { during Qi emission. }\end{array}$ & $\begin{array}{l}\text { Two out of eleven QG trainees emitted } \\
\text { strong magnetic fields during the } \\
\text { emitting time interval. We present } \\
\text { the real-time data and also analyze } \\
\text { characteristic features by the methods } \\
\text { of variance, windowed Fourier } \\
\text { transform, and wavelet transform. } \\
\text { The characteristic frequencies are on a } \\
\text { broad band between } 0.1 \mathrm{~Hz} \text { and } 4 \mathrm{~Hz} \text {. }\end{array}$ \\
\hline $\begin{array}{l}\text { Hisamitsu et } \\
\text { al., } 1996[33]\end{array}$ & OS & NR & Japan & NR & $1 \mathrm{M} 1 \mathrm{~F}$ & Masters & NR & $\begin{array}{l}\text { The biomagnetic field was } \\
\text { measured with differential coils } \\
\text { wound } 80,000 \text { turns, a magnetic } \\
\text { needle compass and a digital } \\
\text { electromagnetic wave detection } \\
\text { device. }\end{array}$ & $\begin{array}{l}\text { To measure the biomagnetic } \\
\text { field emanating from QG }\end{array}$ & $\begin{array}{l}\text { When participant started to perform } \\
\text { breathing, magnetic field of } 200- \\
300 \mathrm{mT} \text { at frequency of } 8-12 \mathrm{~Hz} \\
\text { was emitted. When the rotation of } \\
\text { the needle occurred, a reproducible } \\
\text { magnetic field of } 800-1500 \mathrm{mT} \text { ( } 8-15 \\
\text { mGauss) was indicated on the digital } \\
\text { measuring device tested } 12 \text { times. }\end{array}$ \\
\hline \multicolumn{11}{|l|}{ fMRI } \\
\hline $\begin{array}{l}\text { Yu et al., } \\
2007[34]\end{array}$ & OS & 4 & China & $\begin{array}{l}60 \pm 12 ; \\
\text { range 45-72 }\end{array}$ & M & $\begin{array}{l}\text { Master > } \\
30 \text { yrs }\end{array}$ & NR & $\begin{array}{l}\text { EEG in each of masters was } \\
\text { performed } 1 \text { day before fMRI and } \\
\text { recorded continuously from } 10-15 \\
\text { min after beginning QG practice. } \\
\text { The heart and respiration rate of } \\
4 \text { masters were monitored during } \\
\text { the test. }\end{array}$ & $\begin{array}{l}\text { To assess change of brain } \\
\text { function under QG state with } \\
\text { pain stimulation by fMRI } \\
\text { and other physical index } \\
\text { monitoring including heart } \\
\text { rate and respiration rate }\end{array}$ & $\begin{array}{l}\text { No heart rate change was found between } \\
\text { non QG state and the QG state, and } \\
\text { the mean } \mathrm{HR} \text { was } 65 / \text { min. Before QG } \\
\text { practicing, SI and SII-insula regions, } \\
\text { Brodmann areas, the cingulate cortex, } \\
\text { the thalamus, and the cerebellum were } \\
\text { all activated ( } \mathrm{p}<0,05) \text { while } 15 \text { min after } \\
\text { that, the activated areas were decreased } \\
\text {, which were mainly at the SII-insula } \\
\text { region and Brodmann areas ( }<00.05) \text {. } \\
\text { The response amplitude of the SII-insula } \\
\text { region under the state of QG }(3.5 \%) \text { was } \\
\text { greater than that before QG }(1.2 \%) \text {. }\end{array}$ \\
\hline $\begin{array}{l}\text { Chan et al, } \\
2006[35]\end{array}$ & OS & 10 & $\begin{array}{l}\text { Hong } \\
\text { Kong }\end{array}$ & $\mathrm{M}=29.9$ & M & Masters & NR & $\begin{array}{l}\text { Participants were instructed to } \\
\text { close their eyes and relax for the } \\
\text { duration of the experiment. Each } \\
\text { participated in two two-minute } \\
\text { experimental sessions. The first } \\
\text { session was stimulation of the } \\
\text { Dan Tian. The second session } \\
\text { was stimulation of the right hand } \\
\text { which was applied to the medial } \\
\text { right arm. }\end{array}$ & $\begin{array}{l}\text { To study brain activations } \\
\text { associated with external } \\
\text { stimulation of the lower } \\
\text { Elixir Field }\end{array}$ & $\begin{array}{l}\text { The brain regions activated during Dan } \\
\text { Tian stimulation was more extensive } \\
\text { than those for right-hand stimulation. } \\
\text { The time course analysis, comparing the } \\
\text { blood oxygen level dependent percentage } \\
\text { signal change in the Dan Tian stimulation } \\
\text { with the rest condition showed significant } \\
\text { differences in the right frontal lobe (p } \\
<0.05 \text {, paired t-test) and left temporal } \\
\text { lobe }(\mathrm{p}=0.01 \text {, paired t-test). The signal } \\
\text { changes for the thalamus (right: } \mathrm{p}<0.01 \text {, } \\
\text { left: } \mathrm{p}<0.05 \text { ) and insula (right: } \mathrm{p}<0.01 \text {, } \\
\text { left: } \mathrm{p}<0.01 \text { ) were also significant. }\end{array}$ \\
\hline
\end{tabular}




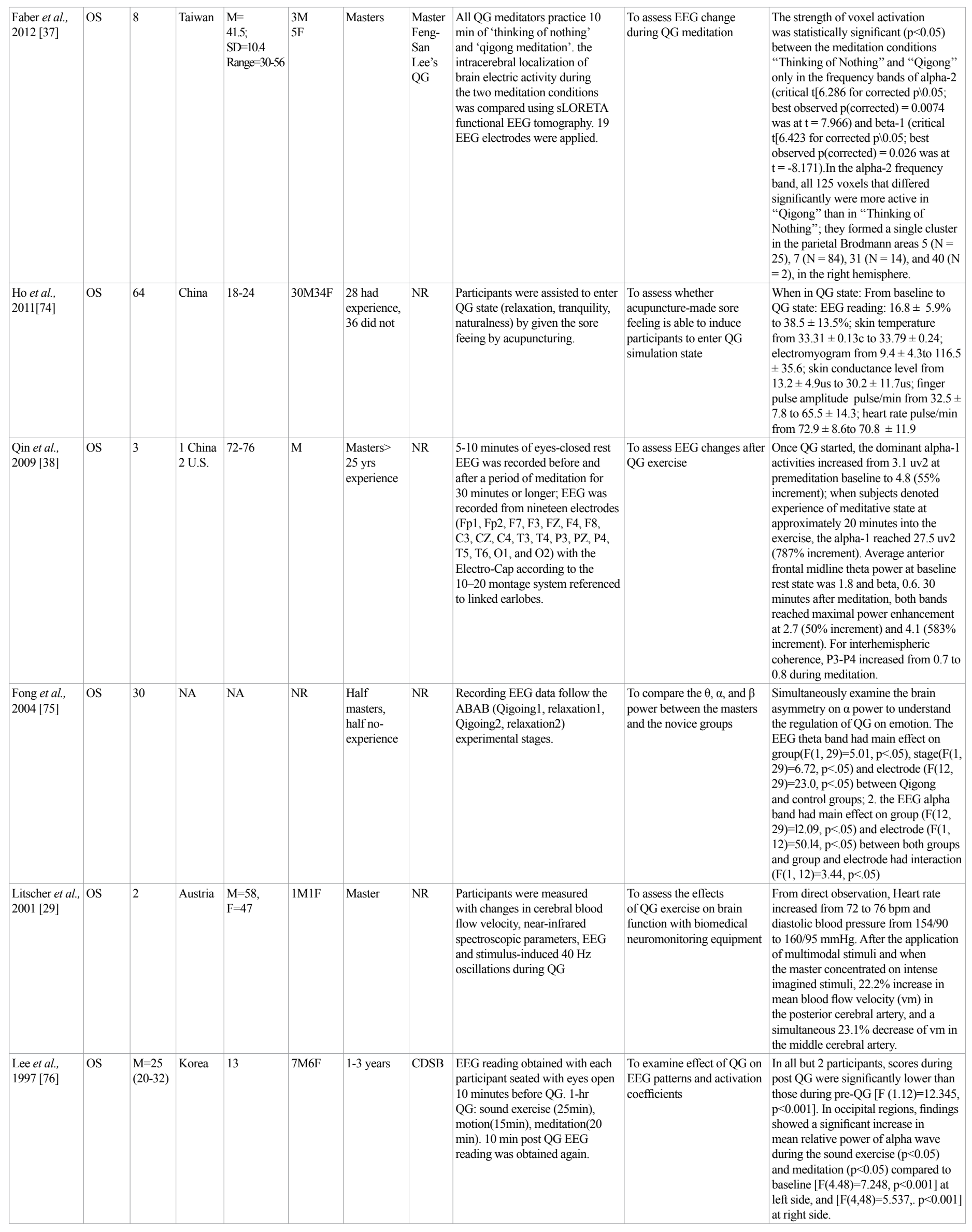




\begin{tabular}{|c|c|c|c|c|c|c|c|c|c|c|}
\hline $\begin{array}{l}\text { Lee } \text { et al., } \\
1994 \text { [47] }\end{array}$ & RCT & 10 & Korea & $\begin{array}{l}23.19 \pm \\
3.44\end{array}$ & NR & None & CDSB & $\begin{array}{l}\text { Participants attended crossover } \\
\text { sessions either in Qi or placebo } \\
\text { with eyes open. One 30-yearold } \\
\text { master with } 8 \text { yr of practice } \\
\text { emitted Qi from head to body on } \\
\text { subjects in External Qi Therapy } \\
\text { (EQT) group, for placebo group } \\
\text { he mimics the gestures used in } \\
\text { the actual EQT with no effort or } \\
\text { intention to emit real Qi. }\end{array}$ & $\begin{array}{l}\text { To assess the effect of } \\
\text { external Qi on changes } \\
\text { of EEG and circulating } \\
\text { cortisol concentrations, and } \\
\text { emotional states }\end{array}$ & $\begin{array}{l}\text { The emotions of satisfaction (Placebo } \\
0.43 \pm 0.98 \text { vs. EQT } 0.86 \pm 1.07, \\
\mathrm{p}<0.05 \text { ) and relaxation (Placebo } 0.43 \\
\pm 0.53 \text { vs. EQT } 0.43 \pm 0.53, \mathrm{p}<0.001 \text { ) } \\
\text { were significantly higher during EQT } \\
\text { than placebo sessions. Significant } \\
\text { differences between two sessions for } \\
\text { all electrode sites. (F3A1 placebo } \\
28 \text { vs. EQT32; F4A2 placebo } 30 \text { vs. } \\
\text { EQT34; O1A1 placebo } 32 \text { vs. EQT 37; } \\
\text { O2A2 placebo30 vs. EQT34; p }<0.05 \text { ). } \\
\text { Plasma cortisol concentrations were } \\
\text { significantly lower during EQT than } \\
\text { during placebo sessions (placebo } 8 \\
\text { mg/dl vs. EQT } 7.2 \mathrm{mg} / \mathrm{dl} ; \mathrm{p}<0.05 \text { ) }\end{array}$ \\
\hline \multicolumn{11}{|l|}{ EMG } \\
\hline $\begin{array}{l}\text { Kuo et al., } \\
2003 \text { [77] }\end{array}$ & OS & 56 & Taiwan & $18-24$ & $\begin{array}{l}20 \mathrm{M} \\
36 \mathrm{~F}\end{array}$ & None & NQ & $\begin{array}{l}\text { Physiological changes are } \\
\text { assessed with EEG in the right } \\
\text { frontal lobe of cerebrum, finger } \\
\text { pylse amplitude (FPA), heart rate, } \\
\text { skin conductance level (SCL), } \\
\text { ECG, EMG (measured from the } \\
\text { dorsum of right hand). }\end{array}$ & $\begin{array}{l}\text { To assess physiological } \\
\text { changes when entering the } \\
\text { QG state (breathing) }\end{array}$ & $\begin{array}{l}\text { Once entering QG state, appearance } \\
\text { of EEG pattern and temperature rise } \\
\text { (17.9 in control, to } 31.7 \text { in QG), change } \\
\text { in EMG (7.9 in control, } 126.7 \text { in QG } \\
\text { state), SCL (13.5 in control; } 31.2 \text { in } \\
\text { QG state), FPA ( } 31.4 \text { in control, } 64.5 \\
\text { in QG) }\end{array}$ \\
\hline $\begin{array}{l}\text { Wirth et al, } \\
1997 \text { [78] }\end{array}$ & $\begin{array}{l}\text { Double- } \\
\text { blind } \\
\text { RCT }\end{array}$ & 44 & China & NR & NR & $\begin{array}{l}\text { Half } \\
\text { experience, } \\
\text { half none }\end{array}$ & NR & $\begin{array}{l}3 \text { groups- students of QG/students } \\
\text { of therapeutic touch (TT)/non- } \\
\text { believers. }\end{array}$ & $\begin{array}{l}\text { To measure the variable } \\
\text { energizing effect of QG } \\
\text { along with the anecdotally } \\
\text { and experimentally } \\
\text { established relaxation effect } \\
\text { of TT therapy relative to } \\
\text { patient belief and expectancy } \\
\text { using sEMG }\end{array}$ & $\begin{array}{l}\text { Significant rise in sEMGfor QG group } \\
\text { during intervention segment }(\mathrm{p}<0.024) \text {; } \\
\text { Treatment Effect of QG group from } \\
\text { baseline to treatment: } 3.65 \text { t07.5; } \\
\text { whereas control of TT decreased from } \\
3.4 \mathrm{o} 3.4 \text {, and non-believers remained } \\
\text { the same at } 3.4\end{array}$ \\
\hline \multicolumn{11}{|c|}{ Evoked Potential Tests } \\
\hline $\begin{array}{l}\text { Zhang et al., } \\
1993 \text { [40] }\end{array}$ & QED & 48 & China & \begin{tabular}{|l|}
$\mathrm{G} 1: 61.9 \pm$ \\
$8.5, \mathrm{G} 2: 48.5$ \\
\pm \\
$15.1, \mathrm{G} 3:$ \\
$54.3 \pm$ \\
11.6 \\
$\mathrm{G} 4: 49.0 \pm$ \\
12.1
\end{tabular} & NR & NR & $\mathrm{NQ}$ & $\begin{array}{l}\text { Flash visual evoked potentials } \\
\text { (F-VEPs) were recorded from the } \\
\text { occipital scalp: Group 1)14 NQ } \\
\text { practitioners for } 0.5-5.5 \text { yrs. 2) } 12 \\
\text { NQ practitioners for } 0.5-3 \mathrm{~m} ; 3 \text { ) } \\
11 \text { none-practitioners; 4) } 11 \text { QG } \\
\text { (non-specified) practitioners }\end{array}$ & $\begin{array}{l}\text { To investigate the functional } \\
\text { state of the cerebral cortex } \\
\text { during QG meditation }\end{array}$ & $\begin{array}{l}\text { QG meditation may have either } \\
\text { facilitative or inhibitory effects on visual } \\
\text { cortex depending on which QG practice. } \\
\text { F-VEP amplitudes increased in Group } 1 \\
\left(\mathrm{~N}_{80}-\mathrm{P}_{115}-\mathrm{N}_{150} \text { increased by } 2,3 \pm 3.4 \text { uv }\right. \\
, \mathrm{p}<0.05 ; \mathrm{N}_{150}-\mathrm{P}_{200}-\mathrm{N}_{280} \text { increased by } 5.1 \\
\pm 5.1 \text { uv, } \mathrm{p}<0.001) \text {, decreased in group } \\
4\left(\mathrm{~N}_{150}-\mathrm{P}_{200}-\mathrm{N}_{280} \text { decreased by } 3.8 \pm 3.8\right. \\
\text { uv, } \mathrm{p}<0.05) \text {, No significant changes in } \\
\text { group } 2(\mathrm{p}>0.05) \text {. }\end{array}$ \\
\hline $\begin{array}{l}\text { Liu et al., } \\
1990 \text { [41] }\end{array}$ & OS & NR & China & $21-54$ & NR & $\begin{array}{l}1-20 \mathrm{yrs} \\
\text { experience }\end{array}$ & NR & $\begin{array}{l}\text { Evoked potentials measured } \\
\text { before, during, after QG, through } \\
\text { Short Latency Auditory Evoked } \\
\text { Potentials (LAEP) }\end{array}$ & $\begin{array}{l}\text { To investigate the effect } \\
\text { of QG on short-latency } \\
\text { auditory brainstem evoked } \\
\text { response (ABER, }<10 \mathrm{~ms} \text { ), } \\
\text { middle-latency response } \\
\text { (MLR, } 10-50 \mathrm{~ms}) \text {, long- } \\
\text { latency auditory evoked } \\
\text { potentials (AER, } 50-200 \mathrm{~ms} \text { ) }\end{array}$ & $\begin{array}{l}\text { Significant increases of amplitudes } \\
\text { of waves from } 55 \text { to } 61 \% \text { ( } \mathrm{p}<0.05) \\
\text { for waves I-III, } 70-76 \% \text { for waves IV } \\
\text { and } \mathrm{V}(\mathrm{p}<0.001) \text {. Waves VI and VII } \\
\text { showed little change }(+5.9 \%,-9.5 \% \text {, } \\
\mathrm{p}>0.05) \text {. Mean latencies of ABER } \\
(\mathrm{n}=21), \text { MLR(n }=11), \text { AER(n }=11) \\
\text { showed no significant changes as a } \\
\text { result of QG. (Statistical Method NR) }\end{array}$ \\
\hline
\end{tabular}

*OS: Observational Study; RCT: Randomized Clinical Trials; QED: Quasi experimental design; ED: Experimental design; EQ: External Qigong; WB: White Ball Standing, QiGong; BDJ: Bah-Duan-Jin; GL: GuoLin Qigong; NQ: Neiyang Qigong; SXPXG: Shu-xin-pin-xue-gong; DD: Dharma Drum's eight-form moving meditation; HQ: Healthy Qigong; NR: Non-reported

EMG are also commonly used to measure the electrical activity of the brain surrounding Qigong [36]. Effects were shown across practitioners of various experiences, ranging from Qigong masters to those with no prior experiences. The effects appear to be most pronounced in the studies conducted among Qigong masters of at least 20-25 years of practice $[37,38]$. However, a recent review study in the physiological effects of biofield-based therapies suggested that EEG changes were inconsistent and may not specific to biofield therapies [39]. Evoked potentials, another electrophysiological recording method, have also been applied to Qigong research. Although signals can be recorded cerebral cortex, visual cortex [40], auditory evokes potential [41], or spinal cord, studies using evoked potentials are limited to measuring the effects of qigong meditation. There is limited pre, during or post data on the physical exercise component of Qigong.

\section{Physiological dynamics methods}

Table 2 presents physiological methods in assessing therapeutic effects of Qigong. Clinical research studies consistently use heart rate variability as a marker of autonomic tone. The majority of the studies included in this review presented HRV either as a primary or secondary outcome or interests. Although most researcher concluded significant changes in heart rate before, during, and after Qigong exercise, there are other observational studies that showed no heart rate changes before or after QG practice [34]. Regarding heart rate variability, a quasi-experimental design study among wheelchair-bound older adults observed no differences between experimental groups and control groups regarding all HRV parameters after 12 weeks of Qigong [42]. Another cross-sectional analysis reported, however, that all HRV parameters were significantly higher in practitioners than those of non-practitioners. The number of years of Tai Chi experience did not correlate with the value of heart rate variability parameters [43]. It is important to note that these study discrepancies may be explained by various Qigong training styles, length of each program, and exercise frequency and intensities [44]. 


\begin{tabular}{|c|c|c|c|c|c|c|c|c|c|c|}
\hline \multirow[t]{2}{*}{ Author, Year } & \multirow{2}{*}{\begin{tabular}{|l} 
Study \\
Design
\end{tabular}} & \multicolumn{6}{|c|}{ Population Characteristics } & \multirow[t]{2}{*}{ Methods } & \multirow[t]{2}{*}{ Outcome of Interests } & \multirow[t]{2}{*}{ Main Findings } \\
\hline & & \# & Country & Age & Sex & $\begin{array}{l}\text { Previous } \\
\text { QG } \\
\text { Practice }\end{array}$ & $\begin{array}{l}\text { Type of } \\
\text { QG }\end{array}$ & & & \\
\hline \multicolumn{11}{|l|}{ Heart Rate } \\
\hline $\begin{array}{l}\text { Chang et al., } \\
2014 \text { [79] }\end{array}$ & QED & 77 & Taiwan & $\begin{array}{l}\text { QG: } 63.0 \\
\pm 6.4 \\
\text { CON:65.1 } \\
\pm 7.4\end{array}$ & $17 \mathrm{M} 60 \mathrm{M}$ & None & DD & $\begin{array}{l}\text { QG participants participated } \\
30 \text { min of eight-form moving } \\
\text { meditation } 3 \text { times per week } \\
\text { for } 12 \text { weeks, control group } \\
\text { continued their normal daily } \\
\text { activities. }\end{array}$ & $\begin{array}{l}\text { To examine the effects QG } \\
\text { on the heart rate variability } \\
\text { and peripheral vasomotor } \\
\text { response of middle-aged } \\
\text { and elderly people in the } \\
\text { community }\end{array}$ & $\begin{array}{l}\text { The t-test and the } \chi 2 \text { test were used to } \\
\text { analyze group differences; the mean } \\
\text { values of SDNN, total power, low } \\
\text { frequency, and high frequency for the } \\
\text { experimental group increased from } \\
26.98,618.86,152.40 \text {, and } 107.03 \\
\text { points to } 32.39,828.95,232.08 \text {, and } \\
157.07 \text { points after the } 12 \text {-week follow- } \\
\text { up (p<0.05) }\end{array}$ \\
\hline $\begin{array}{l}\text { Zhang et al., } \\
2006[80] \\
\text { (In Chinese) }\end{array}$ & CT & 88 & China & $55+$ & $44 \mathrm{M}, 44 \mathrm{~F}$ & None & $\begin{array}{l}\text { WQX } \\
\text { and } \\
\text { YJJ }\end{array}$ & $\begin{array}{l}\text { Participants practice WQX and } \\
\text { YJJ twice a day, } 40 \text { minutes for } \\
\text { each practice, last for } 6 \text { months. } \\
\text { BP, HR, HI, SV, SW, SWI, CO, } \\
\text { CI, TPR, C, BW and BMI were } \\
\text { tested at the beginning of the } \\
\text { intervention, in the middle, and } \\
\text { after intervention }\end{array}$ & $\begin{array}{l}\text { To investigate the effect } \\
\text { of QG on the function of } \\
\text { Cardiac and Cerebral vessel } \\
\text { among older adults }\end{array}$ & $\begin{array}{l}\text { After } 6 \text { months of intervention, there } \\
\text { appeared a trend of improvement of } \\
\text { BP, HR,HI,SV,SW,SWI,CO,CI,TPR } \\
\text { and C for men and women. There } \\
\text { seem to be a gender difference for the } \\
\text { outcome in this study that women, in } \\
\text { general, improved more significantly } \\
\text { than men. For female participants, SBP, } \\
\text { DBP, SV, CO,CI,TPR and C improved } \\
\text { significantly while the significant } \\
\text { improvements for male }\end{array}$ \\
\hline $\begin{array}{l}\text { Lee et al., } 2005 \\
{[81]}\end{array}$ & OS & 40 & Korea & $\begin{array}{l}\text { QG group: } \\
24.1 \pm \\
3.4 ; \mathrm{CON}: \\
23.7 \pm 3.1\end{array}$ & M & None & NR & $\begin{array}{l}\text { Single blinded- } 20 \text { randomized } \\
\text { into QG, } 20 \text { in sham QG. Sham } \\
\text { QG was administered by the } \\
\text { same QG master, who aimed } \\
\text { to mimic the gestures used in } \\
\text { the actual QG with no effort } \\
\text { or intention to emit real Qi. } \\
\text { Participants had } 10 \text { min rest and } \\
\text { their ECGs recorded for } 10 \text { min } \\
\text { (Pre). Following QG (or sham } \\
\text { QG) of } 10 \text { min, they had their } \\
\text { second ECG measured for } 10 \\
\text { min after } 10 \text { min rest (Post). }\end{array}$ & $\begin{array}{l}\text { To examine } \\
\text { electrocardiography (ECG) } \\
\text { parameters- heartrate } \\
\text { variability including Heart } \\
\text { Rate (HR), low frequency } \\
\text { heart rate (LF), high } \\
\text { frequency heart rate (HF), } \\
\text { LF/HF ratio before and } \\
\text { after QG }\end{array}$ & $\begin{array}{l}\text { Paired t-tests show that from pre to } \\
\text { post: } \mathrm{HR} \text { (bpm) QG: } 70.5 \pm 7.1 \text { to } \\
66.9 \pm 5.8 ; \mathrm{CON}: 70.4 \pm 4.3 \text { to } 69.3 \pm \\
2.8 \text { (p<0.05); } \mathrm{LF} \text { (ms } 2 / \mathrm{H}) \mathrm{QG}: 48.7 \pm \\
13.6 \text { to } 34.4 \pm 16.1 ; \mathrm{CON}: 45.3 \pm 14.5 \\
\text { to } 42.0 \pm 21.2(\mathrm{p}<0.05) ; \mathrm{HF}(\mathrm{ms} 2 / \mathrm{Hz}) \\
\text { QG: } 51.3 \pm 13.6 \text { to } 65.6 \pm 16.1 . \mathrm{CON} \text { : } \\
54.8 \pm 14.6 \text { to } 58.0 \pm 21.2(\mathrm{p}<0.05) \mathrm{LF} / \\
\text { HF QG: } 1.10 \pm 0.57 \text { to } 0.65 \pm 0.53 \text {. } \\
\text { CON:1.01 } \pm 0.68 \text { to } 0.99 \pm 0.80\end{array}$ \\
\hline $\begin{array}{l}\text { Lim et al., } \\
1993 \text { [82] }\end{array}$ & OS & 10 & U.S. & $\begin{array}{l}20.50 \pm \\
1.84\end{array}$ & $10 \mathrm{M} 10 \mathrm{~F}$ & None & $\mathrm{N}$ & $\begin{array}{l}\text { Participants participated in a } \\
20-\text {-minute group instructional } \\
\text { session for } 10 \text { consecutive days } \\
\text { before testing of its treatment } \\
\text { effects. The testing protocol } \\
\text { followed a C1-T-C2 design, } \\
\text { where C1, T, and C2 represented } \\
\text { the first, treatment, and second } \\
\text { control period, respectively. Each } \\
\text { period consisted of a 5-minute } \\
\text { interval, and thus each testing } \\
\text { session consisted of } 15 \text { minutes. }\end{array}$ & $\begin{array}{l}\text { To examine effect of QG on } \\
\text { cardio-respiratory changes }\end{array}$ & $\begin{array}{l}\text { One-way analysis results indicated } \\
\text { there was a significant decrease in } \\
\text { respiratory exchange ratio between } \mathrm{T} \\
\text { and } \mathrm{C} 2 \text {. ( } 0.73 \pm 0.06 \text { to } 0.79 \pm 0.04, \\
\mathrm{p}<0.05) \text {. A significant increase in } \\
\text { ventilator efficiency for carbon dioxide } \\
\text { production }(3.88 \pm 0.76 \text { to } 3.13 \pm 0.44) \\
\text { was found between } \mathrm{C} 1 \text { and } \mathrm{T} \text {. }\end{array}$ \\
\hline $\begin{array}{l}\text { Sun et al., } \\
1992 \text { [83] (In } \\
\text { Chinese) }\end{array}$ & OS & 26 & China & $57.8 \pm 8.8$ & $\begin{array}{l}12 \mathrm{M} \\
6 \mathrm{~F}\end{array}$ & Master & Various & $\begin{array}{l}\text { Heart rate (HR) were recorded } \\
\text { when practicing different } \\
\text { QG breathing techniques; } \\
\text { each participant chose } 2 \text { out } \\
\text { of } 4 \text { techniques: A-Kidney- } \\
\text { enhancement Gong }(\mathrm{KG}) \text {, } \\
\text { B-Lung-enhancement Gong (LG), } \\
\text { C-Heart-enhancement Gong (CG), } \\
\text { D-Cancer-removing Gong }\end{array}$ & $\begin{array}{l}\text { To test effects of } \\
4 \text { QG breathing pattern on } \\
\text { variability of heart rate }\end{array}$ & $\begin{array}{l}\text { Direct observations showed that } \\
\text { the amplitude of peak in HR high- } \\
\text { frequency area increased with a } \\
\text { reduction of the low-frequency } 2 / \\
\text { high-frequency (LF2/HF) ratio during } \\
\text { the breathing pattern KG }(0.56 \mathrm{hz}) \text {, } \\
\text { LG( }(0.63 \mathrm{hz}) \text {, and } \mathrm{HG}(0.66) \text {, compared } \\
\text { to normal breathing ( } 2.66 \mathrm{hz}, \mathrm{p}<0.05) \\
\text { indicating the vagal activity increased } \\
\text { QG breathing pattern. }\end{array}$ \\
\hline
\end{tabular}




\begin{tabular}{|c|c|c|c|c|c|c|c|c|c|c|}
\hline $\begin{array}{l}\text { Lan et al., } 2004 \\
{[84]}\end{array}$ & OS & 36 & Taiwan & $59.1(6.6)$ & $36 \mathrm{M}$ & $\begin{array}{l}\text { QG: } \\
\text { practice } \\
\text { for } 2.3 \\
(1.5) \\
\text { years } \\
\\
\text { TCC : } \\
\text { practice } \\
\text { of } 4.7 \\
(2.3) \\
\text { years }\end{array}$ & NR & $\begin{array}{l}\text { Measure cardiorespiratory } \\
\text { function during subsequent } \\
\text { bicycle exercise test: } \\
3 \text { groups: QG (n=12), TCC } \\
\text { (n=12), Sedentary (n=12) } \\
\text { QG: } 10 \text { min warm-up, 30 } \\
\text { min QG, } 10 \text { min concluding } \\
\text { exercises, at least } 3 \mathrm{X} / \text { week led } \\
\text { by instructor } \\
\text { TCC: } 20 \text { min warm-up, } 24 \text { min } \\
\text { TCC, } 10 \text { min cool down, at least } \\
\text { 3x/week let by instructor }\end{array}$ & $\begin{array}{l}\text { To compare } \\
\text { cardiorespiratory responses } \\
\text { among QG practitioners, } \\
\text { TCC practitioners, and } \\
\text { sedentary controls during } \\
\text { cycle ergometer } \\
\end{array}$ & $\begin{array}{l}\text { TCC has highest beneficial effect but } \\
\text { QG still enhances breathing efficiency. } \\
\text { Between } \mathrm{QG} \text { and sedentary at ventilator } \\
\text { threshold. No significant difference } \\
\text { in heart rate }(116 \pm 11 \text { vs. } 111 \pm 20, \\
\mathrm{p}=\mathrm{NS}) \text {. Higher } \mathrm{O} 2 \text { uptake }(15.5 \pm 3.1 \\
\text { vs. } 12.3 \pm 1.9, \mathrm{p}<.05) \text {. Higher } \mathrm{O} 2 \text { pulse } \\
(9.1 \pm 2.2 \text { vs. } 7.2 \pm 1.3, \mathrm{p}<.05) \text {. No } \\
\text { significant difference in work rate ( } 60 \pm \\
20 \text { vs. } 55 \pm 13, \mathrm{p}=\mathrm{NS})\end{array}$ \\
\hline $\begin{array}{l}\text { Jones et al., } \\
2001[45]\end{array}$ & OS & 19 & HK & $27-55$ & $8 \mathrm{M} 11 \mathrm{~F}$ & None & GL & $\begin{array}{l}\text { Numbers of peripheral blood } \\
\text { cytokine-secreting cells were } \\
\text { determined by ELISPOT in, } \\
\text { before participants were taught } \\
\text { the practice of Qigong and } \\
\text { after } 3,7 \text { and } 14 \text { weeks of daily } \\
\text { practice }\end{array}$ & $\begin{array}{l}\text { To test to impact of QG } \\
\text { practice on Blood pressure, } \\
\text { pulse rate, blood cortisol } \\
\text { level and production of } \\
\text { IFN } \gamma \text {, IL4, IL6, IL10, IL12 } \\
\text { and TNF } \alpha\end{array}$ & $\begin{array}{l}\text { Based on direct observation, Pulse rate } \\
\text { decreased from } 76.3 \pm 11.4 \text { (mean } \pm \\
\text { SD) before training to } 69.8 \pm 9.4 \text { at } 3 \\
\text { weeks (p<0.05). Plasma cortisol levels } \\
\text { at baseline were } 394 \pm 115 \mathrm{nmol} / 1 \text { and } \\
\text { at } 3,7 \text { and } 14 \text { weeks were } 328 \pm 126 \\
\text { (p }<0.05 \text { ), } 376 \pm 109 \text { (not significant) } \\
\text { and } 318 \pm 110 \text { (p }<0.05 \text { ) respectively. } \\
\text { Numbers of blood cytokine IL4 and } \\
\text { IL12-secreting cells remained stable. } \\
\text { IL6 increased at } 7 \text { weeks and TNFalpha } \\
\text { increased in unstimulated cultures at } \\
3 \text { and } 7 \text { weeks but decreased at these } \\
\text { times in LPS and SAC-stimulated } \\
\text { cultures. IFNgamma-secreting cells } \\
\text { increased and IL10-secreting cells } \\
\text { decreased in PHA-stimulated cultures, } \\
\text { resulting in significant increases in } \\
\text { the IFNgamma:IL10 ratio. Cortisol, } \\
\text { a known inhibitor of type 1 cytokine } \\
\text { production, was reduced by practicing } \\
\text { QG }\end{array}$ \\
\hline \multicolumn{11}{|l|}{ Blood Pressure } \\
\hline $\begin{array}{l}\text { Lee } \text { et al., } 2000 \\
{[46]}\end{array}$ & OS & 12 & Korea & $28 \pm<9$ & $9 \mathrm{M} 3 \mathrm{~F}$ & $\begin{array}{l}1.3 \pm 0.2 \\
y r s\end{array}$ & CDSB & $\begin{array}{l}\text { Participants practice } \mathrm{QG} 1 \mathrm{hr} / \\
\text { daily ( } 10 \mathrm{~min} \text { sound exercise, } 10 \\
\text { min motion, } 40 \text { min meditation), } \\
6 \text { times/week, directed by a } \\
\text { master }\end{array}$ & $\begin{array}{l}\text { To assess blood pressure, } \\
\text { heart and respiratory rates } \\
\text { during QG exercise }\end{array}$ & 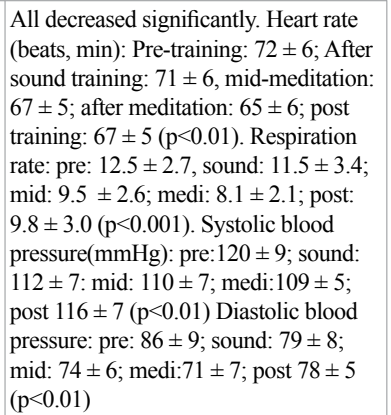 \\
\hline $\begin{array}{l}\text { Zeng et al } \square \\
2013[85] \\
\text { (In Chinese) }\end{array}$ & RCT & $\begin{array}{l}120 ; 60 \text { in } \\
\text { intervention; } \\
60 \text { in control }\end{array}$ & China & $\begin{array}{l}\text { QG: } 66.32 \\
(7.61) \\
60-79 \\
\text { C: } 64.68 \\
(8.25), 60- \\
79)\end{array}$ & $\begin{array}{l}\text { QG: } \\
28 \mathrm{M}, \\
32 \mathrm{~F} \\
\\
\text { C: } 31 \mathrm{M}, \\
29 \mathrm{~F}\end{array}$ & None & FSG & $\begin{array}{l}\text { Participants were divided into } \\
\text { two age groups :60-69;70-79. } \\
\mathrm{BP}^{1}{ }^{1} \text { were tested 5-10 minutes } \\
\text { after performing Relaxation, } \\
\text { meanwhile, HR data were } \\
\text { collected. } \\
\text { participants were diagnosed with } \\
\text { ISH 5-26 years }\end{array}$ & $\begin{array}{l}\text { Effects of FSG on } \\
\text { hypertension }\end{array}$ & $\begin{array}{l}\text { Compare with control group, there's } \\
\text { a statistically significant reduction of } \\
\text { SBP, DBP and DP }{ }^{2} \text { among intervention } \\
\text { group. ( }<0.05 \text { ) } \\
\text { for age range } 60-69 \\
\text { SBP is } 132.37 \pm 6.36 \text { vs. } 140.87 \pm 6.99 \\
\text { DBP is } \\
81.62 \pm 9.42 \text { vs. } 88.63 \pm 11.45 \\
\text { DP is } 51.03 \pm 13.06 \text { vs. } 59.96 \pm 12.36 \\
\text { for age range } 70-79, \\
\text { SBP is } 136.88 \pm 6.39 v s .142 .88 \pm 14.53 \\
\text { DBP is } 81.65 \pm 1.03 \text { vs. } 86.4 \pm 12.08 \\
\text { DP is } 55.28 \pm 2.24 \text { vs. } 59.96 \pm 9.84 \\
\text { HR reduced but not statistically } \\
\text { significant.(P>0.05) }\end{array}$ \\
\hline $\begin{array}{l}\text { Lin and Huang, } \\
2013 \text { [86] (In } \\
\text { Chinese) }\end{array}$ & RCT & 127 & $\begin{array}{l}\text { Hefei, } \\
\text { China }\end{array}$ & $60+$ & $\begin{array}{l}\text { QG: } \\
31 \mathrm{M}, \\
37 \mathrm{~F} \\
\text { C: } 27 \mathrm{M}, \\
32 \mathrm{~F}\end{array}$ & None & WQX & $\begin{array}{l}\text { Intervention N= } 68 \\
\text { Use medicine to control } \\
\text { hypertension, meanwhile, } \\
\text { practice WQX at least } 6 \text { times } \\
\text { a week, } 30 \text { minutes for each } \\
\text { practice. Last for } 6 \text { months, } \\
\text { BP were tested at the beginning } \\
\text { the intervention and after the } \\
\text { intervention. Control group } \\
\text { uses medicine to control } \\
\text { hypertension. }\end{array}$ & $\begin{array}{l}\text { To test effects of WQX } \\
\text { on the intervention of } \\
\text { hypertension senior adults }\end{array}$ & $\begin{array}{l}\text { Compare with control group, there's a } \\
\text { statistically significant improvement of } \\
\text { SBP among intervention group. } \\
\text { SBP: } 130.68 \pm 14.35 \text { vs. } 132.4 \pm 18.00 \\
P<0.05 \\
\text { The change of DBP was not statistically } \\
\text { significant } \\
\text { DBP: } 78.09 \pm 10.23 \text { vs. } 76.03 \pm 10.31\end{array}$ \\
\hline
\end{tabular}




\begin{tabular}{|c|c|c|c|c|c|c|c|c|c|c|}
\hline $\begin{array}{l}\text { Lee et al., } 2003 \\
{[87]}\end{array}$ & RCT & $\begin{array}{l}\text { 58; QG } 29 . \\
\text { CON } 29\end{array}$ & Korea & $\begin{array}{l}\text { QG:56 } \\
(5.9) \\
\\
\text { C: } 56.5 \\
(7.2)\end{array}$ & NR & NR & NR & $\begin{array}{l}\text { QG: Block randomization } \\
10 \text { weeks, 3x/wk, } 30 \text { minutes } \\
\text { QG with expert. Wait list control } \\
\mathrm{n}=29\end{array}$ & $\begin{array}{l}\text { To test the effects of QG } \\
\text { on BP }\end{array}$ & $\begin{array}{l}\text { Qigong significantly lowered BP } \\
\text { compared to control: } \\
\text { Systolic BP: significant group-by-time } \\
\text { interaction }[\mathrm{F}(5,280)=6.70, \mathrm{p}<.001] \\
\text { Diastolic } \mathrm{BP} \text { : significant group-by-time } \\
\text { interaction }[\mathrm{F}(5,280)=2.23 \text {, } \\
\mathrm{p}<.05]\end{array}$ \\
\hline $\begin{array}{l}\text { Cheung et al., } \\
2005 \text { [88] }\end{array}$ & RCT & 8 & HK & $\begin{array}{l}\text { QG: } 57.2 \\
(9.5) \\
\text { C: } 51.2 \\
(7.4)\end{array}$ & $\begin{array}{l}\text { QG: } \\
21 \mathrm{M}, \\
26 \mathrm{~F} \\
\\
\text { C: } 16 \mathrm{M}, \\
25 \mathrm{~F}\end{array}$ & NR & GL & $\begin{array}{l}16 \mathrm{wk}(120 \mathrm{~min} \times 2 \text { days } \times 4 \\
\text { weeks with a QG instructor or } \\
\text { physiotherapist, then monthly } \\
\text { and encouraged to practice } \\
60 \mathrm{~min} \text { in } \mathrm{AM} \text { and } 15 \text { min in } \\
\mathrm{PM} \times 7 \text { days). CON: Exercise } \\
\text { of stretching, walking, and } \\
\text { pressure-relieving activities } \\
\text { similar to QG }\end{array}$ & $\begin{array}{l}\text { To test the effects of QG } \\
\text { versus exercise on } \mathrm{BP}\end{array}$ & $\begin{array}{l}\text { Similar effects of Guolin QG and } \\
\text { convention exercise. } \\
\text { SBP and DBP decreased in both groups } \\
\text { by week } 16 \text { ( } \mathrm{P}<0.001) \text {. } \\
\text { The differences in SBP reduction between } \\
\text { the two groups: } 0.59 \text { mmHg }(95 \% \text { CI: } \\
-3.73,4.91 ; \mathrm{P}=0.79) \\
\text { The differences in DBP reduction } \\
\text { between the two groups: } 1.83 \mathrm{mmHg} \\
(95 \% \text { CI: }-0.75,4.41 ; \mathrm{P}=0.16) \text {. }\end{array}$ \\
\hline $\begin{array}{l}\text { Lee et al., } 2004 \\
\text { [89] }\end{array}$ & RCT & 36 & Korea & $\begin{array}{l}\text { QG: } 52.6 \\
(5.1) \\
\text { C: } 54.3 \\
(5.5)\end{array}$ & NR & None & SXPXG & $\begin{array}{l}\text { QG: } 8 \mathrm{wk}(30 \mathrm{~min} \times 2 \text { days/wk). } \\
\text { Wait list control } \mathrm{N}=19\end{array}$ & $\begin{array}{l}\text { To test the effects of QG } \\
\text { on BP }\end{array}$ & $\begin{array}{l}\text { After } 8 \text { weeks, SBP and DBP of Qigong } \\
\text { group were significantly different to the } \\
\text { control (SBP: } \mathrm{p}<0.001 \text {; DBP: } \mathrm{p}<0.001 \text { ). } \\
\text { Significant changes in SBP and DBP in } \\
\text { qigong group after } 8 \text { weeks (SBP: } 152.0 \\
\pm 10.5 \text { vs. } 137.3 \pm 7.5, \mathrm{p}<0.001 \text {; DBP: } \\
97.2 \pm 6.5 \text { vs. } 83.6 \pm 6.2, \mathrm{p}<0.001 \text { ) and in } \\
\text { DBP in the control group }(93.8 \pm 6.2 \text { vs. } \\
96.8 \pm 4.6, \mathrm{p}<.001 \text { ). }\end{array}$ \\
\hline $\begin{array}{l}\text { Sun et al., } 2008 \\
{[90]} \\
\text { (In Chinese) }\end{array}$ & $\begin{array}{l}\text { Three- } \\
\text { Arm } \\
\text { RCT }\end{array}$ & 60 & China & \begin{tabular}{l|} 
Range: \\
60-69 \\
QG group: \\
65.7 (2.3) \\
Running: \\
$65.3(2.4)$ \\
C: 64.8 \\
$(2.3)$
\end{tabular} & $\begin{array}{l}\text { Male } \\
\text { only }\end{array}$ & None & NR & $\begin{array}{l}\text { TG, TC,HDL-C,LDL-C }{ }^{3} \\
\text { ere tested at the beginning } \\
\text { the intervention and after the } \\
\text { intervention } \\
\text { QG participants first received } 1 \\
\text { week of BDJ tutoring, after the } \\
\text { training session each participant } \\
\text { practice BDJ } 5 \text { days a week, } 30- \\
40 \text { minutes each time. Last for } \\
3 \text { months } \\
\text { QG group: } \mathrm{N}=20 \\
\text { running group: } \mathrm{N}=20 \\
\text { Control Group: } \mathrm{N}=20\end{array}$ & $\begin{array}{l}\text { To investigate the influence } \\
\text { of different exercise } \\
\text { methods on the blood } \\
\text { lipid and physical function } \\
\text { of male senior people in } \\
\text { healthy adults }\end{array}$ & $\begin{array}{l}\text { Compare with control group, there's a } \\
\text { statistically significant improvement of TG, } \\
\text { LDL-C, HDL-C among intervention group. } \\
(p<0.05) \\
\text { TG: } 1.2 \pm 0.13 \text { vs. } 4.73 \pm 0.57 \\
\text { HDL-C: } 1.7 \pm 0.28 \text { vs. } 1.51 \pm 0.19 \\
\text { LDL-C2.31 } \pm 0.22 \text { v. } 272 \pm 0.75(2.69 \pm 0.71) \\
\text { TC=total cholesterol, TG=triglyceride } \\
\text { LDL-C=low-density lipoprotein cholesterol, } \\
\text { HDL-C=high-density lipoprotein } \\
\text { cholesterol }\end{array}$ \\
\hline \multicolumn{11}{|l|}{ Blood Lipids } \\
\hline $\begin{array}{l}\text { Li et al., } \\
2013 \text { [50] (In } \\
\text { Chinese) }\end{array}$ & CT & 48 & China & 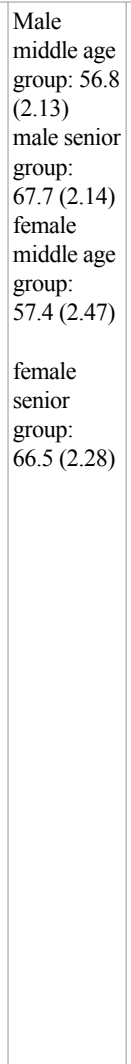 & $24 \mathrm{~F}$ & None & HQ & $\begin{array}{l}\text { Participants practice QG } 1 \\
\text { hour each day, last for } 8 \text { weeks; } \\
\text { TC, TG, HDL-C and LDL-C } \\
\text { were tested at the beginning } \\
\text { the intervention and after the } \\
\text { intervention. }\end{array}$ & $\begin{array}{l}\text { To explore the effect of } \\
\text { QG exercise on blood } \\
\text { lipid metabolism of elder } \\
\text { intellectuals }\end{array}$ & $\begin{array}{l}\text { After } 8 \text { weeks of intervention, there } \\
\text { appeared a trend of improvement of } \\
\text { blood lipid metabolism for both men } \\
\text { and women. There seem to be a gender } \\
\text { difference for the outcome in this study } \\
\text { that women, in general, improved } \\
\text { more significantly than men. For } \\
\text { middle age female participants, HDL-C } \\
\text { and LDL-C improved significantly, } \\
\text { for senior female participants, TC, } \\
\text { TG, HDL-C and LDL-C improved } \\
\text { significantly; for middle age male } \\
\text { participants, HDL-C and LDL-C } \\
\text { improved significantly; for senior male } \\
\text { participants, TG, HDL-C and LDL-C } \\
\text { improved significantly. } \\
\text { Middle age female: } \\
\text { TC: } 4.85 \pm 0.52 \text { vs. } 4.88 \pm 0.55 \\
\text { TG: } 1.25 \pm 0.28 \text { vs. } 1.64 \pm 0.41 \\
\text { HDL-C: } 1.73 \pm 0.34 v s .1 .41 \pm 0.28^{*} \\
\text { LDL-C: } 2.53 \pm 0.4 \text { vs. } 2.93 \pm 0.51^{*} \\
\text { senior female: } \\
\text { TC: } 5.4 \pm 0.28 \text { vs. } 5.82 \pm 0.42^{*} \\
\text { TG: } 1.24 \pm 0.21 \text { vs. } 1.7 \pm 0.27^{*} \\
\text { HDL-C: } 2.02 \pm 0.18 \text { vs. } 1.36 \pm 0.18^{*} \\
\text { LDL-C: } 2.68 \pm 0.28 \text { vs. } 3.44 \pm 0.22^{*} \\
\text { Middle age male: } \\
\text { TC: } 4.38 \pm 0.45 \text { vs. } 4.55 \pm 0.52 \\
\text { TG: } 1.25 \pm 0.2 \text { vs. } 1.31 \pm 0.23 \\
\text { HDL-C: } 1.55 \pm 0.07 \text { vs. } 1.37 \pm 0.22^{*} \\
\text { LDL-C: } 2.27 \pm 0.18 \text { vs. } 2.54 \pm 0.18^{*} \\
\text { senior male: } \\
\text { TC: } 4.57 \pm 0.52 \text { vs. } 4.63 \pm 0.53 \\
\text { TG: } 1.17 \pm 0.11 \text { vs. } 1.41 \pm 0.12^{*} \\
\text { HDL-C: } 1.67 \pm 0.11 \text { vs. } 1.4 \pm 0.05^{*} \\
\text { LDL-C: } 2.31 \pm 0.15 \text { vs. } 2.64 \pm 0.21^{*}\end{array}$ \\
\hline
\end{tabular}




\begin{tabular}{|c|c|c|c|c|c|c|c|c|c|c|}
\hline $\begin{array}{l}\text { Chen and } \\
\text { Chen, 2015 } \\
{[51] \text { (In }} \\
\text { Chinese) }\end{array}$ & Trial & 65 & China & $\begin{array}{l}\text { Middle } \\
\text { age group: } \\
54.8(4.3) \text {, } \\
49-60 \\
\\
\text { Senior } \\
\text { Group:65.2 } \\
(4.6), \\
61-70\end{array}$ & $35 \mathrm{~F}$ & None & BDJ & $\begin{array}{l}\text { At the beginning of the } \\
\text { intervention participants received } \\
1 \text { week Taichi and BDJ training. } \\
\text { Participants then practice Taichi } \\
\text { and BDJ no less than } 3 \text { hour per } \\
\text { week, at least } 40 \text { min each time. } \\
\text { Last for } 3 \text { months } \\
\text { Participants were divided into } 4 \\
\text { subgroup based on their gender } \\
\text { and age. } \\
\text { TC, TG, HDL-C,LDL-C and SF } \\
36 \text { were tested at the beginning } \\
\text { the intervention and after the } \\
\text { intervention. }\end{array}$ & $\begin{array}{l}\text { To explore the effect of } \\
\text { QG exercise on blood lipid } \\
\text { metabolism and life quality } \\
\text { of senior adults. }\end{array}$ & $\begin{array}{l}\text { After } 3 \text { months of intervention, there } \\
\text { appeared a trend of improvement of } \\
\text { blood lipid metabolism and life quality } \\
\text { for both men and women in middle } \\
\text { and senior age groups. There seem to } \\
\text { be a age difference for the outcome } \\
\text { in this study that seniors, in general, } \\
\text { improved more significantly than } \\
\text { middle age participants. For middle } \\
\text { age female participants, none of the } \\
\text { results improved significantly, for } \\
\text { senior female participants, TG, HDL-C } \\
\text { and LDL-C improved significantly; } \\
\text { for middle age male participants, only } \\
\text { HDL-C improved significantly; for } \\
\text { senior male participants, TG, HDL-C } \\
\text { and LDL-C improved significantly. } \\
\text { Middle age female: } \\
\text { TC (mg/dl): } \\
214.1 \pm 40.7 v s .216 .8 \pm 45.8 \\
\text { TG (mg/dl): } \\
157.4 \pm 27.7 v s .163 .5 \pm 32.8 \\
\text { HDL-C (mg/dl): } \\
36.4 \pm 3.4 \text { vs. } 27.3 \pm 3.8 \\
\text { LDL-C (mg/dl): } \\
126.9 \pm 43.7 v s .140 .5 \pm 44.3 \\
\text { senior female: } \\
\text { TC (mg/dl): } \\
242.2 \pm 42.8 v s .261 .7 \pm 33.8 \\
\text { TG (mg/dl): } \\
177.2 \pm 31.2 v s .193 .5 \pm 34.8 * \\
\text { HDL-C(mg/dl): } \\
36.2 \pm 9.8 v s .32 .3 \pm 11.8 * \\
\text { LDL-C (mg/dl): } \\
146.9 \pm 40.2 v s .173 .5 \pm 31.2 * \\
\text { Middle age male: } \\
\text { TC (mg/dl): } \\
226.9 \pm 41.4 v s .242 .8 \pm 43.2 \\
\text { TG (mg/dl): } \\
161.4 \pm 30.5 v s .178 .5 \pm 35.2 \\
\text { HDL-C(mg/dl):33.2 } 7.8 v s .24 .9 \pm \\
6.7 * \\
\text { LDL-C(mg/dl): } \\
131.2 \pm 50.1 v s .166 .3 \pm 48.6 \\
\text { senior male: } \\
\text { TC(mg/dl): } \\
221.1 \pm 40.8 v s .243 .7 \pm 43.6 \\
\text { TG(mg/dl): } \\
164.1 \pm 29.4 v s .182 .6 \pm 33.1 * \\
\text { HDL-C(mg/dl): } \\
29.6 \pm 7.8 v s .23 .4 \pm 9.7 * \\
\text { LDL-C(mg/dl): } \\
134.6 \pm 27.1 \text { vs. } 160.3 \pm 30.6 * \\
\text { SF :77.8 } 14.1 \text { vs. } 68.9 \pm 17.2 \text { p=0.002 }\end{array}$ \\
\hline $\begin{array}{l}\text { Lee } \text { et al., } 2004 \\
\text { [91] }\end{array}$ & RCT & 36 & Korea & $\begin{array}{l}\text { QG: } 52.6 \\
\pm 5.1 ; \\
\text { Control: } \\
54.3 \pm 5.5\end{array}$ & $\begin{array}{l}\text { QG: } \\
\text { 8M9F; } \\
\text { Control } \\
6 \mathrm{M} 13 \mathrm{~F}\end{array}$ & None & SXPXG & $\begin{array}{l}\text { Hypertensive patients were } \\
\text { randomly divided into either } \\
\text { the } \mathrm{QG} \text { group ( } \mathrm{N}=23 \text { ), or a wait- } \\
\text { listed control group (N=24). } \\
\text { During 8-week study, QG group } \\
\text { practices } \mathrm{QG} \text { for } 30 \text { min. Prior } \\
\text { to the intervention (before) and } \\
\text { eight weeks after } \\
\text { (after), } 5 \mathrm{ml} \text { of blood was } \\
\text { collected at } 8 \text { a.m. to measure } \\
\text { lipid metabolism. After } 10 \\
\text { min of rest, the patient's blood } \\
\text { pressure was measured by } \\
\text { the auscultator method }\end{array}$ & $\begin{array}{l}\text { To assess the effectiveness } \\
\text { of Qigong on blood } \\
\text { pressure and several } \\
\text { blood lipids: high-density } \\
\text { lipoprotein (HDL) } \\
\text { cholesterol, Apolipoprotein } \\
\text { A1 (APO-A1), total } \\
\text { cholesterol (TC), and } \\
\text { triglycerides (TG) } \\
\end{array}$ & $\begin{array}{l}\text { There were significant changes in } \\
\text { systolic blood pressure (SBP) and } \\
\text { diastolic blood } \\
\text { pressure (DBP) in the QG group after } \\
\text { eight weeks compared with before } \\
\text { (QG SBP } 152 \text { to } 238, \mathrm{p}<.001 ; \mathrm{QG} \\
\text { DBP } 98 \text { to } 84: \mathrm{p}<.001) \text {. There was } \\
\text { also significant change in the DBPof } \\
\text { the control group ( }<<.01 \text { ). There were } \\
\text { significant differences between the QG } \\
\text { and control groups in HDL ( }<.01 \text { ) and } \\
\text { APO-A1 ( }<<.01) \text {. After eight weeks } \\
\text { of intervention, TC }(\mathrm{p}<.05) \text {, HDL ( }<< \\
.001) \text {, and APO-A1 }(\mathrm{p}<.05 \text { ) changed } \\
\text { significantly compared with before in } \\
\text { the QG group. }\end{array}$ \\
\hline
\end{tabular}

${ }^{1} \mathrm{BP}=\mathrm{Blood}$ Pressure, HR=Heart Rate, $\mathrm{ISH}=$ isolated systolic hypertension

${ }^{2} \mathrm{SBP}=$ systolic blood pressure $\mathrm{DBP}=$ diastolic blood pressure $\mathrm{DP}=$ Double Product

${ }^{3} \mathrm{TC}=$ total cholesterol, $\mathrm{TG}=$ triglyceride LDL-C=low-density lipoprotein cholesterol, HDL-C=high-density lipoprotein cholesterol 
The majority of the empirical studies aiming to quantify Qi started with measuring changes in blood pressure and pulse. A growing number of direct observational studies have consistently shown the decrease of blood pressure and pulse after practicing Qigong [45-47]. Researchers utilized a mix of vital measures including heart rate, respiration rate, systolic blood pressure, diastolic blood pressure to demonstrate the health and clinical effects of Qigong in community-dwelling persons as well as patients with diabetes [1], hypertension [47], or cancer [48]. The recent randomized control trials (RCT) on Qigong exercises show that intervention groups (Qigong) reported a significant reduction of Systolic blood pressure, but not diastolic BP [49]. In addition, most RCT design is only up to 6 months post intervention. Further studies need to be clear about design mechanism as well as length in potential follow-up time.

Other physiological studies which measure blood lipids change in Qigong exercise generally found an improvement of blood lipids metabolism after Qigong. Interestingly, $\mathrm{Li}$ et al. [50] observed a gender difference in the change; compared to 24 male participants enrolled in the trial, female participants $(n=24)$ reported greater and more significant improvement. Similarly, another quasi-trial designed study reported the improvement in blood lipids metabolism was more significant in the older adults groups compared to a younger age group [51]. While both studies show that Qigong practice can improve blood lipids metabolism under well-designed conditions, studies with blood lipids metabolism as the primary outcome of interests were limited to only projects conducted in China. Its generalizability to other racial/ ethnic groups remains to be tested.

\section{Biological materials as detectors}

Given the biological material, such as individual cells and biological molecules such as proteins and antibiotics are assumed to possess Qi (vital energy), and that they may be particularly sensitive to the internal qi or external qi emitted by qigong practitioners; the concept of a biological detector has long been documented in the field of CAM. Table 3 presents biological detectors commonly used in Qigong research.

Measuring indicators of metabolic syndrome including BMI, HDL cholesterol, triglycerides) and glucose control have been linked with understanding the medical effects of Qigong [52]. A recent randomized control trial in diabetic patients in the U.S found that compared to control group, participants in Qigong intervention group reported significant reduction in plasma glucose levels $(\mathrm{p}<0.01)$, and significantly improved fasting glucose $(\mathrm{p}<0.01)$ [53].Using glucose detectors will contribute in understanding the unique presence of Qigong efforts and dynamics.

Biomarkers are generally considered to be proteins or enzymes - measured in serum, plasma, or blood - that provide independent diagnostic and prognostic value by reflecting an underlying disease state. Recent studies on examining the medical effects of Qigong practice have begun to incorporate biomarker assessments mainly in immune parameters including IL6, TNF-a, or ACTH. A direct observational study in Hong Kong reported an increase of IL6 at seven weeks of Qigong practice and that TNF-a increased in un-stimulated cultures at three and seven weeks [45]. In a double-blinded RCT of Qigong vs sham-Qigong study in Korea, Lee et al. [47] reported that there were significant effects of group and time, and group $\mathrm{x}$ time interaction for ACTH levels $(\mathrm{p}<0.05)$. Another RCT study of Qigong conducted in Spain reported that the levels of TNF significantly changed after intervention; Cytokines TNF- $\alpha<(\mathrm{pg} / \mathrm{ml})$ for the control group was 1.89 and IFN- $\gamma(\mathrm{pg} / \mathrm{ml})$ was 10.40 [54]. However, with the exceptions of studies on Qigong meditations, other biomarker studies assessing endorphin or stress hormones remain scarce [55].

Growth hormone is known to undergo large changes in circulating concentrations in response to stimuli such as exercise, sleep and fasting. Growth hormone stimulates the liver and other organs, including the skeleton, to synthesize and secrete insulin-like growth factors (IGF) [56]. In addition, the modulation of immune cells by Qigong therapy may be related to the activity of the sympathetic nervous system (SNS) as well as the neurohormonal axis. Using an observational study design with 10 Korean older adults, Lee et al. [57] argued that that mild movement of Qigong changed somatic growth and enhanced neurohormone concentration and immune functions. Corroborate with this finding, Ryu et al. [58] reported strong correlations between growth hormones and insulin-like growth factor after Qigong practice. These results showed how Qigong training impacted the secretion of growth factors in practitioners, while additional research is now required to determine which aspects of Qigong training contributed to these changes in growth factors, and to ascertain whether exercise in general would result in similar alterations, or if they were augmented by the traditional meditative aspects of Qigong. Observational studies and clinical trials have thus far concluded that Qigong therapy may induce psychological, neurohormonal and immunological changes [59-61].

\section{Discussion}

In summary, our review shows that there has been an increased body of literature on Qigong-related effects concerning physiological processes and variables. Most of these studies suggested that Qigong practice brings significant changes on parameters such as the blood pressure, heart rate variability, decrease of plasma triglycerides, total cholesterol and low-density lipoprotein (LDL) cholesterol, an increase of HDL cholesterol, skin temperature, as well as immunological and neurohormonal enhancements.

These findings show that the bio-physiological effects of Qigong may apply to persons of all age groups, ranging from primary school children, college students to mid-age adults or older adults. Our finding also demonstrates that most of the studies on Qigong-related effects concerning physiological, biological, or CVD-related processes were applied in various chronic disease preventions or intervention studies. We still have the most rudimentary understanding on how these processes may manifest itself in chronic stress reduction or stress management. Overall, many authors only examined stress as secondary outcomes [62]. Trial research has found that Qigong practice may improve certain conditions, especially those that are chronic like musculoskeletal disorders and psychological distress. Type of Qigong and length of practice may influence results. However, many limitations exist, especially concerning study design. More methodological rigorous research exploring the particular pathway of Qigong practice and stress reduction is needed.

Another important methodological issue to consider in understanding physiological effects of qigong pertains to the standardized issues of Qigong practice. From the available data, it appears that there are differences in the bio and physiological outcomes depending on the type of Qigong practiced, making it difficult to draw a concrete conclusion. However, our review was unable to find sufficient evidence that one form of Qigong is more effective than another for any specific condition. Even in studies where results are not significant, it is unclear if it might be a study design limitation or 
Table 3. Biological Detector Measurements of Qigong

\begin{tabular}{|c|c|c|c|c|c|c|c|c|c|c|}
\hline \multirow[t]{2}{*}{ Author, Year } & \multirow{2}{*}{$\begin{array}{l}\text { Study } \\
\text { Design }\end{array}$} & \multicolumn{6}{|c|}{ Population Characteristics } & \multirow[t]{2}{*}{ Methods } & \multirow{2}{*}{$\begin{array}{l}\text { Outcome of } \\
\text { Interests }\end{array}$} & \multirow[t]{2}{*}{ Main Findings } \\
\hline & & $\#$ & Country & Age & Sex & $\begin{array}{l}\text { Previous } \\
\text { QG } \\
\text { Practice }\end{array}$ & $\begin{array}{l}\text { Type of } \\
\text { QG }\end{array}$ & & & \\
\hline \multicolumn{11}{|c|}{ Biochemical Parameters } \\
\hline $\begin{array}{l}\text { Vera } \text { et al., } 2007 \\
{[92]}\end{array}$ & & 29 & Spain & $18-21$ & $14 \mathrm{M} 15 \mathrm{~F}$ & None & BDJ & $\begin{array}{l}16 \text { in } \mathrm{QG}, 13 \text { in control. } \\
\text { QG subjects were } \\
\text { submitted to a qigong } \\
\text { training program for a } \\
\text { period of one month, } \\
\text { practicing qigong for } 30 \\
\text { minutes. Blood sample } \\
\text { were taken before and } \\
\text { after QG. }\end{array}$ & $\begin{array}{l}\text { To analyze the } \\
\text { effects of a qigong } \\
\text { training program on } \\
\text { blood biochemical } \\
\text { parameters of } \\
\text { GOT (glutamic- } \\
\text { oxaloacetic } \\
\text { transaminase), GPT } \\
\text { (glutamic-pyruvic } \\
\text { transaminase), urea } \\
\text { GGT (gamma- } \\
\text { glutamyltransferase) }\end{array}$ & $\begin{array}{l}\text { A between-group analysis of covariance } \\
\text { shows that the effects of experimental } \\
\text { treatment after adjustment for covariants } \\
\text { were found for GOT }(\mathrm{U} / \mathrm{L}) \mathrm{QG}: 16.7 \text {; } \\
\text { Control: } 21.4[\mathrm{~F}(1,22)=10.7, \mathrm{p}=.003] \\
\mathrm{GPT}(\mathrm{U} / \mathrm{L}) \mathrm{QG} \text { : } 16.4 \text {. Control: } 20.7 \text {. } \\
\text { [F(1,22)=4.32, } \mathrm{p}=.04] \text {, urea }(\mathrm{mg} / \mathrm{dl}) \mathrm{QG} \text { : } \\
\text { 27.6, Control: } 33.2[\mathrm{~F}(1,22)=6.51, \mathrm{p}=.02] \text {. } \\
\text { No significant effects were found for total } \\
\text { cholesterol }[\mathrm{F}(1,22)=1.12, \mathrm{p}=.30] \text {, high- } \\
\text { density lipoprotein }[\mathrm{F}(1,22)=1.55, \mathrm{p}=.22] \text {, } \\
\text { low-density lipoprotein }[\mathrm{F}(1,22)=0.07, \\
\mathrm{p}=.78] \text {, triglycerides }[\mathrm{F}(1,22)=0.81, \mathrm{p}=.37] \text {, } \\
\text { phospholipids }[\mathrm{F}(1,22)=1,47, \mathrm{p}=.23] \text {, and } \\
\text { creatinine }[\mathrm{F}(1,22)=0.52, \mathrm{p}=.47]\end{array}$ \\
\hline $\begin{array}{l}\text { Miao et al., } 2009 \\
\text { [93] (In Chinese) }\end{array}$ & RCT & 50 & China & $\begin{array}{l}\text { QG group: } \\
\text { 63.32 (6.35) } \\
\text { Control Group: } \\
63.68(6.8)\end{array}$ & $\begin{array}{l}25 \mathrm{M} \\
25 \mathrm{~F}\end{array}$ & None & BDJ & $\begin{array}{l}\text { BP,TG, TC,HDL-C,LDL-C } \\
\text { were tested at the beginning } \\
\text { the intervention and after } \\
\text { the intervention } \\
\text { QG participants first } \\
\text { learned about BDJ and } \\
\text { then practice QG 5-7 times } \\
\text { per week, each time } 50-60 \\
\text { minutes, last for } 18 \text { months } \\
\text { QG: } 25, \text { CON: } 25 \text { life as } \\
\text { usual }\end{array}$ & $\begin{array}{l}\text { Explore the } \\
\text { effect of BDJ on } \\
\text { blood lipid of } \\
\text { senior adults with } \\
\text { hyperlipidemia. }\end{array}$ & $\begin{array}{l}\text { Compare with control group, there's a } \\
\text { statistically significant improvement } \\
\text { of TC,TG, LDL-C,HDL-C among } \\
\text { intervention group. }(\mathrm{p}<0.05) \\
\text { TC: } 5.26 \pm 0.51 \text { vs. } 5.96 \pm 0.66 \\
\text { TG: } 1.15 \pm 0.16 \text { vs. } 1.46 \pm 0.22 \\
\text { HDL-C: } 1.85 \pm 0.26 \text { vs. } 1.46 \pm 0.22 \\
\text { LDL-C: } 3.32 \pm 0.29 \text { vs. } 3.7 \pm 0.49 \\
\text { (TC=total cholesterol, TG= triglyceride } \\
\text { LDL-C=low-density lipoprotein } \\
\text { cholesterol, HDL-C=high-density } \\
\text { lipoprotein cholesterol) }\end{array}$ \\
\hline $\begin{array}{l}\text { Liang et al., } 2014 \\
\text { [94](In Chinese) }\end{array}$ & RCT & 60 & China & $\begin{array}{l}\text { QG: } 54.8(7.6) \\
\text { C: } 55.7(8.8)\end{array}$ & $\begin{array}{l}\text { QG: } \\
20 \mathrm{M}, \\
10 \mathrm{~F} \\
\mathrm{C}: 18 \mathrm{M}, \\
12 \mathrm{~F}\end{array}$ & None & BDJ & $\begin{array}{l}\text { TG, TC,HDL-C,LDL-C } \\
{ }^{1} \text { were tested at the } \\
\text { beginning the intervention } \\
\text { and after the intervention } \\
30 \text { participants practice } \\
\text { QG } 5 \text { days per week, twice } \\
\text { each day, each practice } \\
\text { last } 20 \text { minutes, last for } 6 \\
\text { months }\end{array}$ & $\begin{array}{l}\text { explore the effect } \\
\text { of BDJ on BP } \\
\text { and blood lipid of } \\
\text { senior adults with } \\
\text { hypertension. }\end{array}$ & $\begin{array}{l}\text { Compare with control group, there's a } \\
\text { statistically significant improvement of } \\
\text { SBP,DBP,TC,TG, LDL-C,HDL-C among } \\
\text { intervention group. }(\mathrm{p}<0.05) \\
\text { SBP: } 136.4 \pm 10.4 \text { vs. } 145.7 \pm 12.3 \\
\text { DBP: } 85.1 \pm 7.5 \text { vs. } 89.5 \pm 7.3 \\
\text { TC: } 4.08 \pm 0.8 \text { vs. } 5.13 \pm 0.84 \\
\text { TG: } 2.12 \pm 0.54 \text { vs. } 2.72 \pm 0.66 \\
\text { HDL-C: } 1.34 \pm 0.35 \text { vs. } 0.98 \pm 0.38 \\
\text { LDL-C: } 2.45 \pm 0.78 \text { vs. } 3.04 \pm 0.77\end{array}$ \\
\hline $\begin{array}{l}\text { Liu } \text { et al., } 2010 \text { [95] } \\
\text { (In Chinese) }\end{array}$ & RCT & 62 & China & $\begin{array}{l}65.7(3.1) \\
62-69\end{array}$ & All F & None & YJJ & $\begin{array}{l}\text { TG, TC,HDL-C,LDL-C } \\
\text {,SOD,GSH-Px and } \\
\text { MDA }{ }^{2} \text { were tested at the } \\
\text { beginning N=32 } \\
\text { Participants practice QG } \\
6 \text { times a week, each time } \\
40-50 \text { minutes with the } \\
\text { teaching of QG masters. } \\
\text { Last for } 6 \text { months. } \\
\text { the intervention and after } \\
\text { the intervention }\end{array}$ & $\begin{array}{l}\text { explore the effect } \\
\text { of YJJ on blood } \\
\text { lipid and free } \\
\text { radical metabolism } \\
\text { of female senior } \\
\text { adults. } \\
\end{array}$ & $\begin{array}{l}\text { Compare with control group, there's a } \\
\text { statistically significant improvement of } \\
\text { LDL-C,HDL-C SOD,GSH-Px and MDA } \\
\text { among intervention group. }(\mathrm{p}<0.05) \\
\text { HDL-C: } 1.79 \pm 0.67 \text { vs. } 1.37 \pm 0.73 \\
\text { LDL-C: } 2.41 \pm 0.53 \text { vs. } 2.57 \pm 0.65 \\
\text { SOD: } 113.92 \pm 14.38 \text { vs. } 103.37 \pm 12.78 \\
\text { GSH-Px : } 167.14 \pm 19.93 \text { vs. } 131.97 \pm \\
20.38 \\
\text { MDA: } 3.98 \pm 0.64 \text { vs. } 4.62 \pm 0.89\end{array}$ \\
\hline \multicolumn{11}{|l|}{ Glucose } \\
\hline Liu et al., 2010 [1] & OS & 11 & Australia & $42-65$ & $3 \mathrm{M} 8 \mathrm{~F}$ & None & KMQG & $\begin{array}{l}\text { A single group pre- and } \\
\text { post- trial; Participants } \\
\text { with elevated blood } \\
\text { glucose attended Tai Chi } \\
\text { QG exercise training } \\
\text { for } 1 \text { to } 1.5 \mathrm{~h}, 3 \text { times } \\
\text { per week for } 12 \text { weeks, } \\
\text { and were encouraged to } \\
\text { practice the exercises at } \\
\text { home. Outcomes assessed } \\
\text { immediately prior to and } \\
\text { after } 12 \text { week program. }\end{array}$ & $\begin{array}{l}\text { To evaluate } \\
\text { the feasibility, } \\
\text { acceptability and } \\
\text { effects of a Tai } \\
\text { Chi and Qigong } \\
\text { exercise program in } \\
\text { adults with elevated } \\
\text { blood glucose. }\end{array}$ & $\begin{array}{l}\text { Significant improvements between } \\
\text { baseline and post-intervention in indictors } \\
\text { of metabolic syndrome: bodyweight } \\
\text { (baseline: } 76.38 \text {; post: } 73.42 ; \text { mean } \\
\text { difference }-2.96 \mathrm{~kg}, \mathrm{p}<0.001 \text { ) BMI (base: } \\
27.83 \text {, post: } 26.78 \text {; mean difference } \\
-1.05, \mathrm{p}<0.001 \text { ), waist circumference } \\
\text { (base: } 93.16 \text {; post: } 90.36 \text {; mean- } 2.80 \mathrm{~cm} \text {, } \\
\text { p }<0.05 \text { ), and systolic (baseline: } 129.73 \text {, } \\
\text { post: } 118.09 ;-11.64 \mathrm{~mm} \mathrm{Hg}, \mathrm{p}<0.01 \text { ) and } \\
\text { diastolic blood pressure (baseline: } 84.55, \\
\text { post: } 74.82 \text {, mean- } 9.73 \text { mm Hg, p }<0.001 \text { ). } \\
\text { Indicator of glycaemic control: HbA1c } \\
\text { (baseline } 5.59 \text {; post } 5.27 \text {; mean }-0.32 \% \text {, } \\
\text { p }<0.01 \text { ), insulin resistance (baseline: } 2.61 \text {, } \\
\text { post } 2.08 \text {; mean }-0.53, \mathrm{p}<0.05 \text { ), }\end{array}$ \\
\hline
\end{tabular}




\begin{tabular}{|c|c|c|c|c|c|c|c|c|c|c|}
\hline Sun et al., 2010 [53] & $\mathrm{RCT}$ & 32 & U.S. & M56.3, SD8.1 & NR & None & NA & $\begin{array}{l}\text { Group } 1(n=11) \text { received } \\
\text { the Qigong intervention, } \\
\text { group } 2(n=10) \text { served } \\
\text { as the control group, } \\
\text { and group } 3(n=11) \\
\text { received the progressive } \\
\text { resistance training (PRT) } \\
\text { intervention as an active } \\
\text { comparator. Participants } \\
\text { in all three groups were } \\
\text { asked to maintain their } \\
\text { conventional diabetes care, } \\
\text { including medications, } \\
\text { diet, and exercise, during } \\
\text { the study. Participants } \\
\text { attended weekly Qigong } \\
\text { or PRT group sessions } 60 \\
\text { min per week) conducted } \\
\text { by certified instructors in } \\
\text { addition to practicing twice } \\
\text { a week at home for } 30 \text { min } \\
\text { per session. }\end{array}$ & $\begin{array}{l}\text { To investigate } \\
\text { the effects of } \\
\text { Qigong relative to } \\
\text { physical exercise } \\
\text { or standard care on } \\
\text { glucose control in } \\
\text { adults with type } 2 \\
\text { diabetes. }\end{array}$ & $\begin{array}{l}\text { Statistically significant reductions in } \\
\text { plasma glucose levels were observed in } \\
\text { the Qigong group ( } 184.9 \pm 35.3 \text { vs. } 161.9 \\
\pm 40.5 \mathrm{mg} / \mathrm{dl}, P=0.003 \text { by paired } t \text { test). } \\
\text { Both the PRT group and the control group } \\
\text { increased plasma glucose levels over } \\
\text { time }(143.8 \pm 35.0 v s .154 .0 \pm 44.7 \text { and } \\
156.4 \pm 36.6 \text { vs. } 168.4 \pm 49.1 \mathrm{mg} / \mathrm{dl}, \\
\text { respectively; not significant [NS]). Fasting } \\
\text { glucose of the QG group significantly } \\
\text { improved compared with that of the PRT } \\
\text { group and the control group }(P<0.003 \\
\text { and } P<0.001, \text { respectively, by one-way } \\
\text { ANOVA). A1C remained unchanged in } \\
\text { the control group during the intervention } \\
(7.9 \pm 0.8 \text { vs. } 7.9 \pm 1.6 \%) \text { but declined } \\
\text { slightly in both the PRT group }(8.6 \pm 1.2 \\
v s .7 .9 \pm 1.6, \mathrm{NS}) \text { and the QG group }(8.8 \\
\pm 1.1 \text { vs. } 8.1 \pm 1.3, \mathrm{NS}) \text {. Fasting plasma } \\
\text { insulin levels increased slightly in both } \\
\text { the PRT group }(24.3 \pm 228.8 \text { vs. } 30.2 \pm \\
39.9, \mathrm{NS}) \text { and the control group }(12.6 \pm \\
4.6 \text { vs. } 20.1 \pm 10, P=0.08) \text { but remained } \\
\text { unchanged during the intervention in the } \\
\text { Qigong group }(13.3 \pm 6.2 \text { vs. } 13.4 \pm \\
5.7, \mathrm{NS}) .\end{array}$ \\
\hline $\begin{array}{l}\text { Youngwanichsetha } \\
\text { et al., } 2013 \text { [96] }\end{array}$ & RCT & 64 & Thailand & M35SDD 5.6 & NA & None & TCQ & $\begin{array}{l}\text { Participants were randomly } \\
\text { assigned to an intervention } \\
\text { group }(n=32) \text { and control } \\
\text { group }(n=32) \text {. Participants } \\
\text { in the intervention group } \\
\text { practiced a 50-min tai chi } \\
\text { qigong exercise program, } \\
\text { three times a week for } 12 \\
\text { weeks during the period of } \\
3-6 \text { months postpartum. } \\
\text { Control group received } \\
\text { usual care. }\end{array}$ & $\begin{array}{l}\text { To investigate } \\
\text { the effect of } \\
\text { tai chi qigong } \\
\text { exercise on plasma } \\
\text { glucose levels } \\
\text { and health status } \\
\text { of postpartum } \\
\text { women with type } 2 \\
\text { diabetes. }\end{array}$ & $\begin{array}{l}\text { A statistically significant reduction in } \\
\text { fasting plasma glucose, glycosylated } \\
\text { hemoglobin and blood pressure were seen } \\
\text { in the intervention group when compared } \\
\text { with the control group }(P<0.05) \text { at } 12 \\
\text { weeks. Mean fasting plasma glucose in } \\
\text { the intervention and control groups at } 12 \\
\text { weeks were } 120.19(\mathrm{SD})=17.51) \mathrm{mg} / \mathrm{dl} \text { and } \\
129.88(\mathrm{SD}=15.23) \mathrm{mg} / \mathrm{dl} \text {, respectively. } \\
\text { There were no significant between-group } \\
\text { differences in body-weight or body-mass } \\
\text { index at trial completion. }\end{array}$ \\
\hline Lee et al., 2004 [47] & RCT & 32 & Korea & $\begin{array}{l}\text { Experiment: } \\
30.5 \pm 5.9 \\
\text { control: } \\
31.2 \pm 7.3\end{array}$ & & & CDSB & $\begin{array}{l}\text { Double blinded; } 32 \\
\text { participants were } \\
\text { randomized to a QG } \\
\text { training group }(25 \\
\text { min exercise; } 15 \text { min } \\
\text { movement; } 20 \mathrm{~min} \\
\text { meditation) and a sham } \\
\text { QG control group who } \\
\text { performed the same } \\
\text { movements without } \\
\text { gathering or moving Qi. } \\
\text { Blood sampling was } \\
\text { completed } \\
\text { within } 30 \text { s and subjects } \\
\text { rested for } 10 \text { min before } \\
\text { the experiment began. }\end{array}$ & $\begin{array}{l}\text { To assess plasma } \\
\text { concentrations of } \\
\text { ACTH, cortisol, } \\
\text { and } \\
\text { Aldosterone of QG } \\
\text { practice }\end{array}$ & 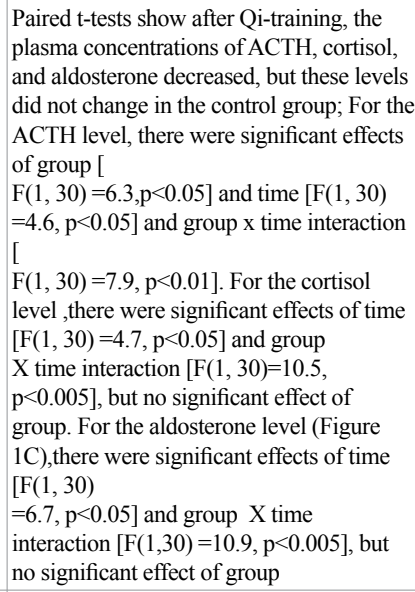 \\
\hline $\begin{array}{l}\text { Iwao et al., } 1999 \\
\text { [97] }\end{array}$ & RCT & 10 & Japan & $\begin{array}{l}54-72,61 \\
\text { median }\end{array}$ & NR & NR & NR & $\begin{array}{l}\text { 30-40 minute duration, } 30 \\
\text { minutes after lunch } \\
\text { CON: Convention walking }\end{array}$ & $\begin{array}{l}\text { Plasma glucose } \\
\text { levels } \\
\text { Pulse rates }\end{array}$ & $\begin{array}{l}\text { Plasma glucose levels decreased during } \\
\text { both exercises (from } 228 \mathrm{mg} / \mathrm{dL} \text { before to } \\
205 \mathrm{mg} / \mathrm{dL} \text { after conventional walking) } \\
\text { and (from } 223 \mathrm{mg} / \mathrm{dL} \text { before to } 216 \mathrm{mg} / \mathrm{dL} \\
\text { after qigong walking). In both situations } \\
\text { the results after exercise decreased more } \\
\text { than those in the group with no exercise } \\
(229 \mathrm{mg} / \mathrm{dL} ; \mathrm{p}<0.025 \text { ). The pulse rates } \\
\text { increased after conventional walking (from } \\
77 \mathrm{to} 95 \text { beats per minute; } \mathrm{p}<0.025 \text { ) and } \\
\text { were higher than those in the group with } \\
\text { no exercise ( } 70 \text { beats per minute; } \mathrm{p}<0.01 \text { ) } \\
\text { and those after qigong walking }(79 \text { beats } \\
\text { per minute; } \mathrm{p}<0.05) \text {. }\end{array}$ \\
\hline
\end{tabular}




\begin{tabular}{|c|c|c|c|c|c|c|c|c|c|c|}
\hline $\begin{array}{l}\text { Yang and Tao, } 2015 \\
\text { [98] (In Chinese) }\end{array}$ & OS & 108 & China & $\begin{array}{l}\mathrm{M}=69.8(7.8) \\
\text { range 51-90 }\end{array}$ & $\begin{array}{l}54 \mathrm{M}, \\
54 \mathrm{~F}\end{array}$ & none & BDJ & $\begin{array}{l}\text { Participant practice BDJ } \\
5-7 \text { times per week, } 35-40 \\
\text { minutes each time, last for } \\
6 \text { months. TBIL,DBIL and } \\
\text { IBIL }^{3} \text { were tested before } \\
\text { and after the intervention }\end{array}$ & $\begin{array}{l}\text { To investigate the } \\
\text { effect of BDJ on } \\
\text { bilirubin level of } \\
\text { type } 2 \text { diabetes } \\
\text { patients }\end{array}$ & $\begin{array}{l}\text { After } 6 \text { months of intervention, TBIL, } \\
\text { DBIL and IBIL improved significantly. } \\
\text { TBIL: } 13.6 \pm 5.4 \text { vs. } 20.1 \pm 7.2, \mathrm{p}<0.01 \\
\text { DBIL: } 3.5 \pm 1.8 \text { vs. } 4.1 \pm 2.1 . \mathrm{p}<0.01 \\
\text { IBIL: } 10.1 \pm 3.9 \text { vs. } 15.8 \pm 5.3, \mathrm{p}<0.01\end{array}$ \\
\hline \multicolumn{11}{|c|}{ Inflammatory Markers } \\
\hline $\begin{array}{l}\text { Oh et al., } 2010 \text { RCT } \\
\text { [99] }\end{array}$ & & 162 & Australia & $\begin{array}{l}\text { QG M: } 60.1 \\
\text { (11.7); CON M: } \\
59.9(11.3)\end{array}$ & $\begin{array}{l}\text { QG } \\
\text { M:31 } \\
\text { F48; } \\
\text { CON } \\
\text { M38, } \\
\text { F45 }\end{array}$ & NR & $\begin{array}{l}\text { Modified } \\
\text { from } \\
\text { traditional } \\
\text { QG }\end{array}$ & 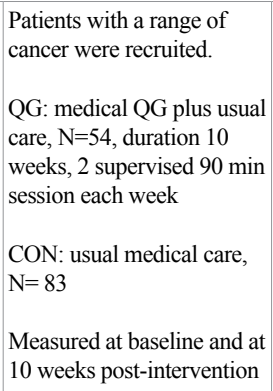 & $\begin{array}{l}\text { To evaluate the } \\
\text { use of Medical } \\
\text { Qigong compared } \\
\text { with usual care } \\
\text { to improve } \\
\text { inflammation } \\
\text { (Serum CRP) of } \\
\text { cancer patients. } \\
\end{array}$ & $\begin{array}{l}\text { QG group significantly improved } \\
\text { inflammatory marker serum C-reactive } \\
\text { protein }(C R P)\left(t_{99}=2.042, P<0.044\right) \\
\text { compared with usual care after controlling } \\
\text { for baseline variables. Mean difference } \\
\text { between groups: }-23.17(-37.08-9.26)\end{array}$ \\
\hline $\begin{array}{l}\text { Oh et al., } 2008 \text { RCT } \\
{[100]}\end{array}$ & & 30 & Australia & $\begin{array}{l}\text { Age 35-75, } \\
M=54(9)\end{array}$ & $8 \mathrm{M} 22 \mathrm{~F}$ & NR & $\begin{array}{l}\text { Modified } \\
\text { from } \\
\text { traditional } \\
\text { QG }\end{array}$ & $\begin{array}{l}\text { Patients with a range of } \\
\text { cancer were recruited. } \\
\text { QG: medical QG plus usual } \\
\text { care, } \mathrm{N}=15 \text {, duration } 8 \\
\text { weeks, } 2 \text { supervised } 90 \text { min } \\
\text { session each week } \\
\text { CON: }=15 \text { usual medical } \\
\text { care }\end{array}$ & $\begin{array}{l}\text { To evaluate the } \\
\text { use of Medical } \\
\text { Qigong compared } \\
\text { with usual care } \\
\text { to improve } \\
\text { inflammation } \\
\text { (Serum CRP) of } \\
\text { cancer patients }\end{array}$ & $\begin{array}{l}\text { The QOL change scores from pre- to post- } \\
\text { Medical Qigong intervention group were } \\
\text { significant for global quality of life (student } \\
\mathrm{t}=-3.989, \mathrm{p}=0.005 \text { ), cognitive function } \\
\text { (student } \mathrm{t}=-2.646, \mathrm{p}=0.033 \text { ) and social } \\
\text { function (student } \mathrm{t}=-2.393, \mathrm{p}=0.048 \text { ), } \\
\text { but non-significant for physical function } \\
\text { (student } \mathrm{t}=-1.000, \mathrm{p}=0.351 \text { ), role } \\
\text { function (student } \mathrm{t}=-0.447, \mathrm{p}=0.668 \text { ), } \\
\text { and emotional function (student } \\
\mathrm{t}=-1.843, \mathrm{p}=0.108 \text { ) }\end{array}$ \\
\hline \multicolumn{11}{|l|}{ Salivary Biomarkers } \\
\hline $\begin{array}{l}\text { Chan et al., } 2013 \\
\text { [101] }\end{array}$ & RCT & 34 & Singapore & NR & NR & NR & NR & $\begin{array}{l}\text { QG was practiced twice a } \\
\text { week by the study group } \\
(n=18) \text { while a control } \\
\text { group }(n=16) \text { had no } \\
\text { intervention. }\end{array}$ & \begin{tabular}{|l|}
$\begin{array}{l}\text { To measure stress } \\
\text { reduction by } \\
\text { salivary biomarkers }\end{array}$ \\
\end{tabular} & $\begin{array}{l}\text { Increases in secretion rates of salivary } \\
\text { immunoglobulin-A, and decreases in } \\
\text { salivary cortisol concentrations were seen } \\
\text { only in the Qigong group }\end{array}$ \\
\hline $\begin{array}{l}\text { Sousa et al., } 2012 \\
\text { [102] }\end{array}$ & $\begin{array}{l}\text { Prospective } \\
\text { Controlled } \\
\text { Intervention }\end{array}$ & 16 & Portugal & $\begin{array}{l}\mathrm{QG} \mathrm{M}=11.5 \\
\mathrm{SD}=0.7 ; \mathrm{CON}: \\
\mathrm{M}=12, \mathrm{SD}=0.0\end{array}$ & NR & None & WQ & $\begin{array}{l}\text { QG was practiced over } \\
\text { seven weeks, twice a week, } \\
\text { for } 30 \text { min with a waiting } \\
\text { list design and instructions } \\
\text { to perform the same } \\
\text { exercises at home daily. } \\
\text { Control group: wait-list } \\
\text { design }\end{array}$ & $\begin{array}{l}\text { To understand } \\
\text { performance- } \\
\text { related anxiety and } \\
\text { physiological stress } \\
\text { functions }\end{array}$ & $\begin{array}{l}\text { Heart rate: } \mathrm{QG} \text { group decreased }(107.0 \\
\pm 21.8 \text { to } 96.0 \pm 18.9 ; \mathrm{M}=-11 \pm 7 \text { ) and } \\
\text { increased in } \mathrm{CON} \text { group }(81.0 \pm 9.5 \text { to } 86.0 \\
\pm 7.2 ; \mathrm{M}=5 \pm 9) ; \mathrm{p}<0.01 \text {. } \\
\text { Salivary cortisol levels: Both } \mathrm{QG}(5.46 \\
\pm 1.51 \text { to } 2.82 \pm 1.58 \mathrm{M}=-0.265 \pm 0.165) \\
\text { and } \mathrm{CON}(4.56 \pm 5.00 \text { to } 3.21 \pm 3.91 ; \mathrm{M}=- \\
0.132 \pm 0.306 \text { ) decreased; difference not } \\
\text { significant (p=0.282) }\end{array}$ \\
\hline $\begin{array}{l}\text { Chow et al. 2012, } \\
{[103]}\end{array}$ & OS & 68 & $\mathrm{HK}$ & $\begin{array}{l}\mathrm{M}=44.2 . \\
\mathrm{SD}=11.0\end{array}$ & $\begin{array}{l}23 \mathrm{M}, \\
45 \mathrm{~F}\end{array}$ & None & CMG & $\begin{array}{l}\text { The changes in outcomes } \\
\text { over four repeated } \\
\text { measures: pretest (week 1), } \\
\text { midway (week 4), posttest } \\
\text { (week 8), and follow-up } \\
\text { (week 12). Salivary cortisol } \\
\text { was assayed using ELISA } \\
\text { kit. Data collection was } \\
\text { done in the morning. The } \\
\text { subjects were required to } \\
\text { rest for } 15-20 \text { min before } \\
\text { blood pressure and heart } \\
\text { rate were taken. Then, they } \\
\text { were given standardized } \\
\text { questionnaires to complete. } \\
\text { After that, salivary samples } \\
\text { were collected. }\end{array}$ & $\begin{array}{l}\text { To measure stress } \\
\text { reduction by } \\
\text { salivary biomarkers } \\
\text { and blood pressure }\end{array}$ & $\begin{array}{l}\text { T-test results show } Q G \text { group had } \\
\text { significantly lower systolic }(\mathrm{F}[1,63]=4.08 \text {, } \\
\mathrm{p}=.048) \text { and diastolic blood pressure } \\
(\mathrm{F}[1,63]=4.37, \mathrm{p}=.041) \text { than the wait list } \\
\text { control group after } 8 \text { weeks of qigong } \\
\text { intervention In week } 12 \text {, with increased } \\
\text { significant levels and effect sizes, the } \\
\text { qigong group experienced lower systolic } \\
\text { blood pressure ( } \mathrm{F}[1,63]=6.59, \mathrm{p}=.013) \\
\text { diastolic blood pressure }(\mathrm{F}[1,63]=4.49, \\
\mathrm{p}=.038), \text { and lower cortisol levels } \\
(\mathrm{F}[1,62]=15.91, \mathrm{p}\end{array}$ \\
\hline
\end{tabular}




\begin{tabular}{|c|c|c|c|c|c|c|c|c|c|c|}
\hline $\begin{array}{l}\text { Bayat- Movahed et } \\
\text { al., } 2008 \text { [104] }\end{array}$ & OS & 23 & Iran & $22-24$ & $10 \mathrm{M} 13 \mathrm{~F}$ & None & YQG & \begin{tabular}{|l||} 
The unstimulated saliva \\
volume and pH were \\
recorded every week \\
in Spring (April, May, \\
June) 2005 before the \\
volunteers started to learn \\
and exercise Qigong, and \\
after Qigong intervention \\
in Spring (April, May, \\
June) 2006.Parameters \\
of unstimulated saliva, \\
including volume, pH and \\
secretory immunoglobulin \\
A (S-IgA) level
\end{tabular} & \begin{tabular}{|l|} 
To measure effects \\
of a Qigong \\
program on various \\
salivary parameters
\end{tabular} & $\begin{array}{l}\text { The unstimulated saliva volume after } \\
\text { Qigong exercises }(2.94 \mathrm{~d} 0.20 \mathrm{~mL} / 5 \mathrm{~min}) \\
\text { was significantly higher as compared to the } \\
\text { pre Qigong phase }(1.65 \mathrm{~d} 0.102 \mathrm{~mL} / 5 \mathrm{~min} \text {, } \\
\text { P. The saliva pH was } 7.116 \mathrm{~d} 0.137 \text { for the } \\
\text { measurements and } 6.980 \mathrm{~d} 0.087 \text { for the } \\
\text { second measurements, and the difference } \\
\text { was not statistically significant. The level } \\
\text { of salivary S-IgA was } 105.45 \mathrm{~d} 69.41 \mathrm{mg} / \\
\mathrm{mL} \text { for the first measurement and } 156.23 \mathrm{~d} \\
88.56 \mathrm{mg} / \mathrm{mL} \text { for the second measurement, } \\
\text { which showed a statistically significant } \\
\text { difference between the two measurements } \\
\text { of salivary S-IgA }(\mathrm{P}=0.005) \text {. }\end{array}$ \\
\hline \multicolumn{11}{|l|}{ Immune Parameters } \\
\hline \multicolumn{11}{|l|}{ NK Cells } \\
\hline Lee et al., 2003 [59] & RCT & 60 & Korea & $\begin{array}{l}\text { Intervention: } 37 \\
\pm 12 ; \text { Control: } \\
35 \pm 17)\end{array}$ & NR & None & CDSB & \begin{tabular}{|l|} 
Double blinded- \\
Participants were \\
randomized to a Qi-training \\
group (who performed Qi- \\
training; $n=30$ ) and sham \\
QG control group (who \\
performed the same \\
motions without gathering \\
or moving Qi; $n=30$ ). \\
Immune cell numbers \\
were measured pre- \\
intervention, immediately \\
post-intervention and 1 or 2 \\
hours post-intervention
\end{tabular} & $\begin{array}{l}\text { To compare sham } \\
\text { QG (placebo: } \\
\text { without intention } \\
\text { of gathering or } \\
\text { moving } \\
\text { Qi) with real QG } \\
\text { to investigate } \\
\text { the effects of } \\
\text { QG on immune } \\
\text { cells, including } \\
\text { NK, neutrophils, } \\
\text { lymphocyte }\end{array}$ & $\begin{array}{l}\text { Paired t-tests show that White blood } \\
\text { cells increased significantly } 2 \text { hours after } \\
\text { actual QG (Pre: } 5.68 \pm 1.36 ; \text { post: } 5.67 \pm \\
1.32 ; 2 \text {-hr post: } 6.12 \pm 1.29 ; \mathrm{p}<0.05) \\
\text { but not sham training compared with } \\
\text { pre-intervention. There were significant } \\
\text { increases in lymphocytes } 2 \text { hours after } \\
\text { actual but not sham QG (pre: } 2.05 \pm 0.52 ; \\
\text { post: } 2.04 \pm 0.51 ; 2 \text {-hr post: } 2.20 \pm 0.52 ; \\
\text { p }<0.05 \text { ) and monocyte numbers were } \\
\text { significantly increased immediately after } \\
\text { both actual QG (pre: } 0.44 \pm 0.26 ; \text { post: } \\
0.67 \pm 0.51 ; 2 \text {-hr post: } 0.44 \pm 0.16 ; \mathrm{p} \\
<0.01 \text { and sham training (pre: } 0.40 \pm \\
0.08 ; \text { post: } 0.44 \pm 0.12 ; 2 \text {-hr post: } 0.45 \pm \\
0.11 \mathrm{p}<0.05 \text { ). NK cell numbers decreased } \\
\text { significantly both immediately after QG } \\
\text { and after sham movements done without } \\
\text { concomitant Qi-training }(\mathrm{p}<0.01) \text {. There } \\
\text { were no significant effects on neutrophils. }\end{array}$ \\
\hline $\begin{array}{l}\text { Yu et al., } 2008 \text { [105] } \\
\text { (In Chinese) }\end{array}$ & RCT & 100 & China & $\begin{array}{l}\mathrm{QG} \mathrm{M}=46, \\
\mathrm{CON} \mathrm{M}=50\end{array}$ & $\begin{array}{l}\text { QG } 12 \mathrm{M}, \\
34 \mathrm{~F} . \\
\text { CON } \\
15 \mathrm{M}, \\
35 \mathrm{~F}\end{array}$ & None & WQX & $\begin{array}{l}\text { NK cell activity was tested } \\
\text { at the beginning of the } \\
\text { intervention and after the } \\
\text { intervention. } \\
\text { QG participants practice } \\
\text { QG at least } 4 \text { times a week, } \\
30 \text { minutes each time for } \\
6 \text { months. Con: Daily life } \\
\text { were kept as usual }\end{array}$ & $\begin{array}{l}\text { To explore the } \\
\text { effect of WQX } \\
\text { exercise on NK cell } \\
\text { activity of senior } \\
\text { adults } \\
\end{array}$ & $\begin{array}{l}\text { Compared with control group, there's a } \\
\text { statistically significant improvement of NK } \\
\text { cell activity among intervention group. } \\
\text { Male: } \\
29.04 \pm 11.46 \text { vs. } 24.64 \pm 8.43 \\
\text { Female: } \\
27.86 \pm 15.65 \text { vs. } 21.44 \pm 7.78\end{array}$ \\
\hline $\begin{array}{l}\text { Vera et al., } 2015 \\
{[106]}\end{array}$ & RCT & 43 & Spain & $18-21$ & $9 \mathrm{M} 34 \mathrm{~F}$ & None & DQ & $\begin{array}{l}25 \text { participants were } \\
\text { randomly allocated to the } \\
\text { experimental group and } \\
18 \text { to the control group. } \\
\text { The experimental subjects } \\
\text { underwent daily qigong } \\
\text { training for } 1 \text { month. } \\
\text { Blood samples for the } \\
\text { quantification of immune } \\
\text { parameters (number and } \\
\text { percentage of monocytes, } \\
\text { neutrophils, eosinophils, } \\
\text { total lymphocytes, B } \\
\text { lymphocytes, and natural } \\
\text { killer (NK) cells) were } \\
\text { taken the day before the } \\
\text { experiment commenced } \\
\text { and } 1 \mathrm{~h} \text { after the last } \\
\text { session of the training } \\
\text { program ended. }\end{array}$ & $\begin{array}{l}\text { To examine acute } \\
\text { effect of QG on } \\
\text { the counts of } \\
\text { innate and adaptive } \\
\text { immune cells in } \\
\text { human peripheral } \\
\text { blood after 1 month } \\
\text { of QG practice }\end{array}$ & $\begin{array}{l}\text { After } 1 \text { month: Differences were found } \\
\text { between the experimental and control } \\
\text { groups, with the experimental group } \\
\text { showing higher NK cells values ( } 234.62 \\
\text { cells/ } \mu \text { l) compared to control group } \\
(195.51 \text { cells/ } / \text { l) in the number }(p=0.006) \\
\text { and the percentage }(10.72 \% v s .9 .40 \% \text {; } \\
p=0.04) \text { of B lymphocytes, as well as } \\
\text { lower values in the percentage of NK } \\
\text { cells }(16.26 \% \text { vs. } 18.96 \%, p=0.05) \text {, as } \\
\text { compared to control. }\end{array}$ \\
\hline
\end{tabular}




\begin{tabular}{|c|c|c|c|c|c|c|c|c|c|c|}
\hline $\begin{array}{l}\text { Lee } \text { et al., } 2005 \\
{[107]}\end{array}$ & RCT & 18 & Korea & $\begin{array}{l}\text { Experiemental: } \\
26.8 \pm 1.2 \\
\text { control: } 26.1 \\
\pm 1.7 \text { ) }\end{array}$ & M & None & CDSB & $\begin{array}{l}9 \text { experimental subjects } \\
\text { did } 1 \mathrm{~h} \text { of } Q \mathrm{G} \text { under a } \\
\text { master; consisted of } 10 \mathrm{~min} \\
\text { resting, } 15 \text { reciting; } 15 \text { slow } \\
\text { movement; } 20 \text { meditation, } \\
\text { and } 9 \text { control participants } \\
\text { relaxed during the same } \\
\text { time; not required to do } \\
\text { anything. Blood was drawn } \\
10 \text { min before } \\
\text { QG, within } 10 \text { min of the } \\
\text { end of } Q G \text {, and } 2 \mathrm{~h} \text { after } \\
\text { QG. Human peripheral } \\
\text { blood was obtained } \\
\text { by venipuncture using } \\
\text { heparinized syringes }\end{array}$ & $\begin{array}{l}\text { To access acute } \\
\text { effect of QG on } \\
\text { natural killer cell } \\
\text { (NK) and cytotoxic } \\
\text { activity } \\
\end{array}$ & $\begin{array}{l}\text { For cells incubated for } 4 \mathrm{~h} \text {, } \\
\text { there was a significant main effect of time [ } \\
\mathrm{F}(2,32)=3.4, \mathrm{p}=.046] \text { and time } \times \text { group } \\
\text { interaction }[\mathrm{F}(2,32)=6.3, \mathrm{p}=.005] \text {, but no } \\
\text { significant group effect. For cells incubated } \\
\text { for } 16 \mathrm{~h} \text {, only the time } \times \text { group interaction } \\
\text { was significant }[\mathrm{F}(2,32)=4.5, \mathrm{p}=.019] \text {. } \\
\mathrm{NKCA} \\
\text { Increased significantly after Qi-training. } \\
\text { Immediately after training, cytotoxic } \\
\text { activity was } 80 \% \text { above control values in } \\
\text { the cells incubated for } 4 \mathrm{~h} \text {, and } 60 \% \text { above } \\
\text { control values in cells incubated for } 16 \mathrm{~h} \text {. } \\
\mathrm{NK} \text { cell cytotoxicity and NK cell number } \\
\text { were not significantly correlated }(\mathrm{r}=.272 \text {, } \\
\mathrm{p}=.17) \text { in the } \mathrm{QG} \text { group }\end{array}$ \\
\hline $\begin{array}{l}\text { Jung et al., } 2006 \\
{[108]}\end{array}$ & OS & 24 & Korea & $\begin{array}{l}\text { QTNM: } 25 \pm \\
\text { 5; QTT-M: } 26 \\
\pm 3\end{array}$ & M & None & $\begin{array}{l}\text { CSEH } \\
\text { External } \\
\text { Qi }\end{array}$ & $\begin{array}{l}\text { Participants were } \\
\text { randomized into QTN- } \\
\text { received external Qi } \\
\text { without touching (N=12) } \\
\text { or QTT- received Qi with } \\
\text { touching (N=12). Hormone } \\
\text { assays including serum } \\
\text { levels of cortisol and } \\
\text { melatonin are collected. } \\
\text { Immunological function } \\
\text { including neutrophils and } \\
\text { NK cell are measured. } \\
\text { Participants are measured } \\
\text { pre (10 min before), post I } \\
\text { (10 min after) and post II (1 } \\
\text { hour after) qi therapy. }\end{array}$ & $\begin{array}{l}\text { To examine } \\
\text { whether there } \\
\text { are differences } \\
\text { between QG } \\
\text { healing touching } \\
\text { and non-touching } \\
\text { in hormone assays } \\
\text { and immunological } \\
\text { function }\end{array}$ & $\begin{array}{l}\text { Nonparametric statistical tests revealed no } \\
\text { significant differences between the effects } \\
\text { of QTN and QTT (all p }>.05 \text { ). Separate } \\
\text { Wilcox signed rank tests showed that: } \\
\text { Cortisol (g/dl): QTN Pre 7.4(6.1-8.5), } \\
\text { post I 5.8 (5.4-7.2), post II 4.4 (4.1-5.6); } \\
\text { p }<0.001 \text {; vs. QTT 7.2 (5.9-7.8), post I } \\
\text { 7.1(6.0-7.5), post II 5.0(4.6-5.7). Melatonin } \\
\text { (pg/ml) QTN: pre 7.2(5.9-7.8), post I 7.1 } \\
\text { (6.0-7.5), post II 5.0 (4.6-5.7), p=0.039. } \\
\text { Superoxide generation (107 cpm) QTN: pre } \\
\text { 3.7 (2.9-4.1), post I 4.3(3.4-5.4), post II 3.5 } \\
\text { (2.9-4.3), p }<0.001 \text { QTT pre 3.5 (2.7-3.6), } \\
\text { post I 3.4 (2.9-4.0). post II 3.2 (2.7-3.9). } \\
\text { P }>0.05 . \text { NK Cell (\%) QTN pre 44.2 (40.5- } \\
\text { 51.1), post I 66.9 (54.2-78.6), post II 49.9 } \\
(45.0-61.3), \text { p }<0.001 \text { QTT pre 44.8 (37.3- } \\
\text { 58.1), post I 55.9 (46.5-70.5), post II 49.4 } \\
\text { (40.6-52.8), p }<0.01\end{array}$ \\
\hline \multicolumn{11}{|c|}{ - Growth Harmone } \\
\hline Lee et al., 2005[57] & OS & 10 & Korea & $\begin{array}{l}\mathrm{M}=66 \\
\mathrm{SD}=3\end{array}$ & NR & None & CDSB & $\begin{array}{l}\text { 1-hour QG practice; } \\
\text { comprised resting for } 10 \\
\text { min, } \\
\text { followed by three kinds of } \\
\text { exercise: sound recitation } \\
\text { for } 15 \text { min, slow motions } \\
\text { for } 15 \text { min, and meditation } \\
\text { for } 20 \text { min. Peripheral } \\
\text { blood was drawn } \\
\text { from the median cubital } \\
\text { vein before QG (Pre) and } \\
\text { after the QG(Post) }\end{array}$ & $\begin{array}{l}\text { To examine effects } \\
\text { of QG on immune } \\
\text { function and } \\
\text { neurohormone } \\
\text { concentrations }\end{array}$ & $\begin{array}{l}\text { Significant increase in growth hormone } \\
\text { (GH) after } 1 \mathrm{~h} \text { QG compared with the } \\
\text { Pre samples (Pre: } 0.38 \pm 0.9 \mathrm{ng} / \mathrm{ml} \text {; Post: } \\
0.66 \pm 0.8, \\
\mathrm{p}<.01) \text {. After } 1 \mathrm{~h} \mathrm{QG}, \mathrm{O} 2-\text { generation was } \\
\text { significantly higher than the Pre level (Pre: } \\
4.57 \pm 0.48 \mathrm{ng} / \mathrm{mL} ; \text { Post: } 5.97 \pm 0.49, \\
\mathrm{p}<.05 \text { ), but no change in the number of } \\
\text { neutrophils was observed in the peripheral } \\
\text { blood. A significant increase in the O2- } \\
\text { production of production by neutrophils } \\
\text { (PMN) incubated with the serum collected } \\
\text { after Qi-training was observed }(\mathrm{p}<.05 \text { ) } \\
\text { compared with pre- training serum. }\end{array}$ \\
\hline $\begin{array}{l}\text { Lee et al., } 1999 \\
{[109]}\end{array}$ & OS & 26 & Korea & $\begin{array}{l}\text { Older age } \\
\text { group: } \\
\mathrm{M}=59.86+- \\
1.92 \text {, Younger } \\
\text { age } \mathrm{M}=26.58+- \\
1.03\end{array}$ & $\begin{array}{l}\text { 14M, } \\
12 \mathrm{~F}\end{array}$ & $\begin{array}{l}>0.6 \text { year of } \\
\text { experience }\end{array}$ & CDSB & $\begin{array}{l}10 \mathrm{ml} \text { blood was drawn } \\
\text { at pre (10-min before } \\
\text { training), mid (before } \\
\text { meditating), post-training }\end{array}$ & $\begin{array}{l}\text { To observe the } \\
\text { response of plasma } \\
\text { growth hormone } \\
\text { (GH), insulin-like } \\
\text { growth factor-I } \\
\text { (IGF-I) and } \\
\text { testosterone (T) to } \\
\text { an acute period of } \\
\text { ChunDoSunBup } \\
\text { (CDSB) Qi- } \\
\text { training. }\end{array}$ & $\begin{array}{l}\text { Although the basal level of GH was not } \\
\text { different between the two groups, after the } \\
\text { portion of the training in which the subjects } \\
\text { were physically active (the mid-training } \\
\text { point), plasma GH levels increased by } \\
7.26 \text { fold (p }<0.05 \text { ) in the elderly trainees } \\
\text { and by } 1.66 \text { fold (p }<0.05 \text { ) in the young. } \\
\text { In response to CDSB Qi-training, IGF-I } \\
\text { levels in the young increased significantly } \\
\text { at mid-training point, but there were } \\
\text { no increase in the elderly. Significant } \\
\text { correlations existed between GH and IGF-I } \\
\text { levels in the young subjects, but not in the } \\
\text { elderly. The T level at the mid-training } \\
\text { point increased significantly in elderly } \\
\text { subjects but not in the younger age. }\end{array}$ \\
\hline
\end{tabular}




\begin{tabular}{|c|c|c|c|c|c|c|c|c|c|c|}
\hline Ryu et al., 2000 [58] & OS & 16 & Korea & $\begin{array}{l}\mathrm{M}=29 ; \text { contrl } \\
\mathrm{M}=26\end{array}$ & M & $\begin{array}{l}>6 \text { months } \\
\text { experience }\end{array}$ & CDSB & $\begin{array}{l}10 \text { participants in } \mathrm{QG}, 6 \\
\text { in sedentary comparison } \\
\text { group. Blood was drawn at } \\
\text { rest, pre-time of Qi-training } \\
\text { [that is } 10 \text { min before Qi- } \\
\text { training }(210 \text { min)], at } 40 \\
\text { min (the mid-time of Qi- } \\
\text { training, the time between } \\
\text { motions and meditation), } \\
\text { and immediately after the } \\
\text { Qi-training [within } 10 \text { min } \\
(+10 \text { min)] }\end{array}$ & $\begin{array}{l}\text { To examine the } \\
\text { acute effect of QG } \\
\text { on the plasma level } \\
\text { of growth hormone } \\
\text { (GH), insulin-like } \\
\text { growth factor } \\
\text { (IGF)-I and insulin } \\
\text { like growth factor }\end{array}$ & $\begin{array}{l}\text { The plasma level of } \mathrm{GH} \text { at the mid-time } \\
(40 \mathrm{~min}) \text { has significantly increased } \\
(2.16+0.48 \mathrm{ng} / \mathrm{ml}, \mathrm{P}, 0.05) \text { compared to } \\
\text { the level at pre-time of } \mathrm{QG}(1.26 \pm 0.37 \\
\mathrm{ng} / \mathrm{ml}) \text {. The plasma level of IGF-I was } \\
\text { significantly increased at the mid-time } \\
(286.40 \pm 15.97 \mathrm{ng} / \mathrm{ml}) \text { compared to the } \\
\mathrm{pre}-\text { time of Qi-training }(245.57 \pm 13.90 \\
\mathrm{ng} / \mathrm{ml}, \mathrm{p}<0.05) \text { There was a significant } \\
\text { correlation between the levels of GH } \\
\text { and IGF-I immediately after Qi-training } \\
(\mathrm{r}=0.69, \mathrm{P}, 0.01) \text {. There was a relative shift } \\
\text { in IGFBP-3 for the } 43-\mathrm{kDa} \text { fraction during } \\
\text { mid-time of Qi-training }(\mathrm{P}, 0.05)\end{array}$ \\
\hline \multicolumn{11}{|l|}{ - Cytokines } \\
\hline $\begin{array}{l}\text { Manzaneque et al. } \\
\text { 2009, [54] }\end{array}$ & RCT & 39 & Spain & $18-21$ & $5 \mathrm{M} 34 \mathrm{~F}$ & None & BDJ & $\begin{array}{l}\text { Experimental participants } \\
\text { were submitted to a QG } \\
\text { training program consisting } \\
\text { of three group 30-min } \\
\text { session a week of one } \\
\text { month. Control participants } \\
\text { were not required to do } \\
\text { anything in particular }\end{array}$ & $\begin{array}{l}\text { Assess the } \\
\text { effects of qigong } \\
\text { practice on serum } \\
\text { cytokines, mood } \\
\text { and subjective } \\
\text { sleep quality }\end{array}$ & $\begin{array}{l}\text { The practice of QG for one month did } \\
\text { not alter serum cytokines. Cytokines } \\
\text { TNF- } \alpha\langle(\mathrm{pg} / \mathrm{ml}) \text { for control group was } \\
1.89 \text { and IFN- } \gamma(\mathrm{pg} / \mathrm{ml}) \text { was } 10.40 \text {. For } \\
\text { intervention group CTNF- } \alpha \text { was } 1.90 \text {, } \\
\text { IFN- } \gamma \text { was } 10.10 . p \text { value was } 0.99 \text { and } \\
0.81 \text { respectively. }\end{array}$ \\
\hline $\begin{array}{l}\text { Ryu et al., } 1995 \\
{[110]}\end{array}$ & OS & 65 & Korea & $20-50$ & M & Various & CDSB & $\begin{array}{l}\text { Group1 had QG training } \\
\text { for 1-4 month }(\mathrm{N}=12) \text {, } \\
\text { G2 5-12 months }(\mathrm{N}=21) \text {, } \\
\text { G3 13-24 months }(\mathrm{N}=17) \text {, } \\
\text { G4 }>25 \text { months }(\mathrm{N}=12) \\
\text { There is also control group } \\
(\mathrm{N}=13)\end{array}$ & $\begin{array}{l}\text { To examine the } \\
\text { effect of Qigong } \\
\text { training on } \\
\text { proportions of T } \\
\text { lymphocyte subsets } \\
\text { was investigated in } \\
\text { human peripheral } \\
\text { blood }\end{array}$ & $\begin{array}{l}\text { Two-tailored students t-test and ANOVA } \\
\text { tests were used. Participants in G1 }(2.19 \\
\pm 0.29), \mathrm{G} 2(2.41 \pm 0.16), \mathrm{G} 3(2.38 \pm 0.21) \\
\text { and G4 }(2.39 \pm 0.26) \text { had higher ratio of } \\
\text { CD4+/CD8+ T lymphocytes than control } \\
\text { group }(1.64 \pm 0.14) \text {. The ratio of CD4+/ } \\
\text { CD8+ T lymphocytes was increased } 50 \% \\
\text { in a trainee group who practiced Qigong } \\
\text { training more than } 5 \text { months compared } \\
\text { to a normal healthy group who did not } \\
\text { practice. The absolute number of CD4+ T } \\
\text { lymphocytes was also elevated in trainee } \\
\text { group with } 100 \text { cells } / \mathrm{mm}^{3} \text { more than in } \\
\text { normal healthy group. }\end{array}$ \\
\hline $\begin{array}{l}\text { Yao et al., } 1989 \\
{[111]}\end{array}$ & OS & 23 & China & $\mathrm{M}=32(14-69)$ & $8 \mathrm{M} 5 \mathrm{~F}$ & None & Various & $\begin{array}{l}10 \text { in QG group who do 1-hr } \\
\text { daily more than } 1 \text { month, } \\
\text { combing } 5 \text { QG: breathing, } \\
\text { stepping, meditation, kidney- } \\
\text { enhancement. Control: } \\
\text { patient aplastic anemia } \\
\text { without QG practice }\end{array}$ & $\begin{array}{l}\text { To understand the } \\
\text { changes of T-cell } \\
\text { with QG practice } \\
\text { in patients with } \\
\text { aplastic anemia }\end{array}$ & $\begin{array}{l}\text { QG participants Th and the ratio of Th/ } \\
\text { Ts were greatly elevated than those } \\
\text { without Qigong treatment (Leu } 3 \mathrm{n}+: \text { QG } \\
38.3 \pm 6.7 \text {, CON } 29.1 \pm 9.1, \mathrm{p}<0.02 ; \text { Leu } \\
3 \mathrm{n}+/ \text { leu } 2 \mathrm{a}+\mathrm{QG} 1.18 \pm 0.41, \text { CON } 0.77 \pm \\
0.29, \mathrm{p}<0.02 \text { ) }\end{array}$ \\
\hline \multicolumn{11}{|c|}{ Blood Cells and Antioxidant Capacity } \\
\hline Yeh et al., 2006 [48] & $\begin{array}{l}\text { QED/ } \\
\text { CCT }\end{array}$ & 67 & Taiwan & $\begin{array}{l}<39: 12,40- \\
49: 27,>50: 28\end{array}$ & F & None & CCQG & $\begin{array}{l}\text { All breast cancer patients } \\
\text { about to undergo first } \\
\text { chemo; } 32 \text { in experiment } \\
\text { receive } 21 \text {-day QG therapy, } \\
35 \text { in control did not. } \\
\text { White blood cells, platelet, } \\
\text { and hemoglobin were } \\
\text { measured on the day before } \\
\text { chemotherapy and on } \\
\text { days } 8,15 \text {, and } 22 \text { during } \\
\text { chemotherapy }\end{array}$ & $\begin{array}{l}\text { To examine the } \\
\text { effects of QG on } \\
\text { complete blood } \\
\text { counts in breast } \\
\text { cancer patients } \\
\text { treated with } \\
\text { chemotherapy }\end{array}$ & $\begin{array}{l}\text { T-Test results show there were significant } \\
\text { differences over the 3-week therapy in } \\
\text { white blood cells between experiment } \\
\text { grop and control group in white blood cells } \\
\text { (QG Baseline:5820 microliters, W1:3580, } \\
\text { W2:1955, W3:5356. CON B: 6166, W2: } \\
\text { 3661, W3:1955, W4:6236. F = 115.76, } \\
\text { P<0.001), platelets (QG Baseline: 246,228 } \\
\text { microliters, W1: 194,523, W2: 217,222, W3 } \\
\text { 312,000. CON: Base: 263,687, W1:189500. } \\
\text { W2:217,600, W3:356,000. F }=25.29, \text { p }<0 \\
.001 \text { ), and hemoglobin (QG-Baseline: 12.36, } \\
\text { W1: 11,44, W2:11,32, W4:12.09; CON- } \\
\text { B:12.75, W1:11.89, W2:11.42, W3:12.34. F } \\
=15.39, \mathrm{P}<0.001)\end{array}$ \\
\hline
\end{tabular}




\begin{tabular}{|c|c|c|c|c|c|c|c|c|c|c|}
\hline $\begin{array}{l}\text { Wu et al., } 2011 \\
\text { [113] }\end{array}$ & ССT & 55 & China & $\begin{array}{l}\text { M: 55-61, } \\
\text { F:50-60 }\end{array}$ & $\begin{array}{l}33 \mathrm{M}, \\
22 \mathrm{~F}\end{array}$ & NR & WQX & $\begin{array}{l}\text { Obese older adults } \\
\text { practiced QG for } 2 \mathrm{hr} \\
\text { everyday for a year. } \\
\text { Measures taken once every } \\
\text { three months. MDA, TC, } \\
\text { TG, LDL-c and HDL-c } \\
\text { levels, SOD, CAT, GSH-Px } \\
\text { activities were measured }\end{array}$ & $\begin{array}{l}\text { To examine the } \\
\text { effect of QG } \\
\text { on antioxidant } \\
\text { enzymes activities, } \\
\text { lipid peroxidation } \\
\text { level, intestine } \\
\text { probiotics in obese } \\
\text { old people } \\
\end{array}$ & 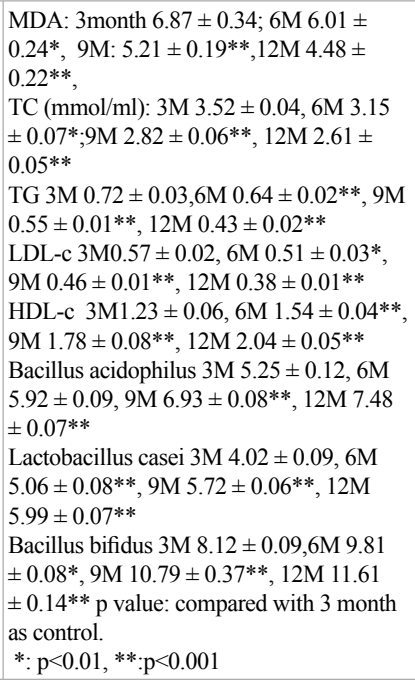 \\
\hline \multicolumn{11}{|c|}{ Hormones and Thyroid Hormones } \\
\hline $\begin{array}{l}\text { Kim et al., } 2013 \\
{[114]}\end{array}$ & OS & 20 & Korea & NR & F & NR & NR & \begin{tabular}{|l|} 
An experimental group \\
and a control group were \\
randomly organized with \\
10 women respectively, and \\
QG training was provided \\
three times a week during a \\
12-week period of time
\end{tabular} & $\begin{array}{l}\text { Body composition } \\
\text { and aging-related } \\
\text { hormone }\end{array}$ & $\begin{array}{l}\text { Decrease of their body fat mass and body } \\
\text { fat percentage, and the increase of their } \\
\text { growth hormone and estrogen. }\end{array}$ \\
\hline $\begin{array}{l}\text { Ryu et al., 2006, } \\
\text { [55] }\end{array}$ & OS & 20 & Korea & $\mathrm{M}=28$ & NR & Yes & CDSB & $\begin{array}{l}\text { Various forms of stress } \\
\text { influence the balance of } \\
\text { HPA axis in men. Blood } \\
\text { was drawn at pre (-10min), } \\
\text { mid ( } 40 \text { min), post }(70 \mathrm{~min}) \\
\text { of training. Plasma was } \\
\text { collected. }\end{array}$ & $\begin{array}{l}\text { To examine the } \\
\text { plasma level of } \\
\text { beta-endorphin, } \\
\text { ACTh cortisol, and } \\
\text { DHEA-S response } \\
\text { to Qi training }\end{array}$ & $\begin{array}{l}\text { Plasma cortisol and DHEA-S during mid } \\
\text { training were not different from the pre- } \\
\text { training }(\mathrm{p}>0.05) \text {. The plasma level of beta- } \\
\text { endorphin during mid-time of qi training } \\
(25.08 \mathrm{pg} / \mathrm{ml}) \text { has increased compared to } \\
\text { pre-training }(11.21 \mathrm{pg} / \mathrm{ml})(\mathrm{p}<0.05)\end{array}$ \\
\hline $\begin{array}{l}\text { Moon et al., } 2004 \\
\text { [115] }\end{array}$ & OS & 25 & Korea & $26-29$ & M & NR & CDSB & $\begin{array}{l}16 \text { men participated in a } \\
\text { study of neuroendocrine } \\
\text { effects of Qi-training, and } \\
\text { nine healthy young men } \\
\text { participated in a study of } \\
\text { the immunological effects. } \\
\text { Nine men volunteered to } \\
\text { draw the blood sample } \\
\text { for in vitro experiment } \\
\text { of growth hormone on } \\
\text { neutrophil responses. } \\
\text { Blood was drawn before } \\
\text { Qitraining [Pre, that is } 10 \\
\text { min before Qi-training] } \\
\text { and immediately after the } \\
\text { Qi-training [Post, within } 10 \\
\text { min }(+10 \text { min)]. }\end{array}$ & $\begin{array}{l}\text { To examine the } \\
\text { effect of Qi- } \\
\text { training on the } \\
\text { plasma levels of } \\
\text { GH and IGF-I, } \\
\text { and investigate the } \\
\text { immunological } \\
\text { effects of Qi } \\
\text { training by } \\
\text { neutrophils' } \\
\text { superoxide } \\
\text { generation, and } \\
\text { adhesion capacity } \\
\end{array}$ & $\begin{array}{l}\text { The plasma GH level was increased after } \\
\text { Qi-training compared to pre Qi-training } \\
(\mathrm{p}<.01) \text {. The plasma level of IGF-1 was } \\
\text { significantly increased after Qi-training } \\
(\mathrm{p}<.05) \text {. Superoxide generation was } \\
\text { significantly enhanced after Qi-training } \\
\text { compared to before Qi-training }(\mathrm{p}<.01) \text {. } \\
\text { The adhesive capacity of neutrophils was } \\
\text { significantly enhanced after Qi-training } \\
(\mathrm{p}<.05) \text {. Significant priming of human } \\
\mathrm{neutrophils} \text { by } \mathrm{GH} \text { was observed at } 10 \\
\mathrm{ng} / \mathrm{ml}(\mathrm{p}<.05), 100 \mathrm{ng} / \mathrm{ml}(\mathrm{p}<.01) \text {, and } \\
250 \mathrm{ng} / \mathrm{ml}(\mathrm{p}<.05) \text {. According to the } \\
\text { dose-response curve, we selected one } \\
\text { submaximal dose as } 250 \mathrm{ng} / \mathrm{ml}(\mathrm{p}<.05) \text {. }\end{array}$ \\
\hline M. S. Lee et al. [51] & OS & 15 & Korea & $\begin{array}{l}\mathrm{M}=60.93 \\
(2.37), \text { age } \\
\text { range 49-81 }\end{array}$ & $10 \mathrm{M}, 5 \mathrm{~F}$ & $\begin{array}{l}\text { Mean 1.98 } \\
(0.21), 1-3 \\
\text { years of } \\
\text { training }\end{array}$ & CDSB & $\begin{array}{l}\text { Blood drawn } 10 \text { min before } \\
\text { training, before mediation, } \\
\text { and post-training } \\
1 \text { hour of qi-training }(10- \\
\text { min rest, } 15 \text { min sound } \\
\text { recitation, } 15 \text { min slow } \\
\text { motions, } 20 \text { min mediation })\end{array}$ & $\begin{array}{l}\text { Investigate how } \\
\text { systemic treatment } \\
\text { of CDSB on } \\
\text { hormones on } \\
\text { elderly subjects }\end{array}$ & $\begin{array}{l}\text { 1) } \mathrm{T} 3 \text { concentrates increased }(1.84 \pm 0.07 \\
\text { to } 1.93 \pm 0.07 \text { to } 1.99 \pm 0.07 \mathrm{nmol} / 1, \mathrm{p}<.05) \\
\text { at pre-, mid-, and post-training. } \\
\text { T4 concentrates increased }(92.43 \pm 5.68 \text { to } \\
99.8 \pm 5.7 \mathrm{nmol} / \mathrm{l}, \mathrm{p}<.05) \text { between pre- and } \\
\text { mid-training } \\
\text { 2) No significant differences in } \mathrm{TSH}(1.10 \\
\pm 0.20 \text { to } 1.16 \pm 0.21 \text { to } 1.24 \pm 0.22 \mathrm{uUU} / \\
\mathrm{ml}) \text {, Calcitonin }(7.41 \pm 0.55 \text { to } 7.80 \pm 0.63 \\
\text { to } 8.24 \pm 0.87 \mathrm{pg} / \mathrm{ml}) \text {, Calcium }(8.99 \pm \\
0.27 \text { to } 9.16 \pm 0.21 \text { to } 8.54 \pm 0.18) \text {, and } \mathrm{pH} \\
\text { (7.88 } \pm 0.03 \text { to } 7.86 \pm 0.02 \text { to } 7.89 \pm 0.02) \\
\text { at pre-, mid-, and post-training }\end{array}$ \\
\hline
\end{tabular}




\begin{tabular}{|c|c|c|c|c|c|c|c|c|c|c|}
\hline $\begin{array}{l}\text { Lee et al., } 2003 \\
{[116]}\end{array}$ & OS & 9 & Korea & $\mathrm{M}=26 \pm 4$ & $9 \mathrm{M}$ & $\begin{array}{l}\text { Age } 26 \\
\pm 4\end{array}$ & CDSB & $\begin{array}{l}\text { Subjects were studied } \\
\text { for the effects of one } \\
\text { bout of ChunDoSunBup } \\
\text { (CDSB) Qi-training on } \\
\text { superoxide (O2- production } \\
\text { and adhesion capacity } \\
\text { of neutrophils at times } \\
\text { immediately after (Post I) } \\
\text { and } 2 \text { hours after the Qi- } \\
\text { training (Post II). }\end{array}$ & $\begin{array}{l}\text { To examine the } \\
\text { effect of Qi-training } \\
\text { on the immune } \\
\text { system, especially } \\
\text { neutrophil } \\
\text { bactericidal } \\
\text { function }\end{array}$ & $\begin{array}{l}\text { The Qi-training enhanced superoxide (O2- } \\
\text { production), reaction velocity and } \\
\text { neutrophil adhesion capacity and there } \\
\text { were significant differences at Post I } \\
\text { compared to before Qi-training (Pre). In } \\
\text { addition, the number of white blood cells } \\
\text { (WBC), monocytes and lymphocytes were } \\
\text { changed significantly through Qi-training. } \\
\text { Significant effects of Qi-training on } \\
\text { reaction velocity [F( } 2,16)=4.95, \mathrm{p}=0.02] \\
\text { and neutrophil adhesive capacity }[\mathrm{F}(2,16) \\
=3.92, \mathrm{p}=0.04] \text {. There were significant } \\
\text { increases in the number of WBC }[\mathrm{F}(2,16) \\
=11.27, \mathrm{p}<0.001], \text { monocytes }[\mathrm{F}(2,16) \\
=14.31, \mathrm{p}<0.001] \text { and lymphocytes }[\mathrm{F}(2, \\
16)=4.6, \mathrm{p}=0.026] \text { after Qi-training. }\end{array}$ \\
\hline $\begin{array}{l}\text { Manzaneque } \text { et al. } \\
2004 \text { [60] }\end{array}$ & RCT & 29 & Spain & $18-21$ & $\begin{array}{l}14 \mathrm{M} \\
15 \mathrm{~F}\end{array}$ & None & BDJ & $\begin{array}{l}16 \text { were allocated to the } \\
\text { experimental group and } \\
\text { the rest to the control } \\
\text { group. The experimental } \\
\text { subjects underwent a } \\
\text { qigong training program, } \\
\text { conducted by a qualified } \\
\text { instructor, consisting } \\
\text { of half an hour of daily } \\
\text { practice for one month. The } \\
\text { day before the experiment } \\
\text { commenced and the day } \\
\text { after it f nished, blood } \\
\text { samples were drawn from } \\
\text { all subjects for the quantify } \\
\text { cation of immunological } \\
\text { parameters }\end{array}$ & $\begin{array}{l}\text { To analyze the } \\
\text { effects of a qigong } \\
\text { program on various } \\
\text { immunological } \\
\text { parameters; } \\
\text { including the } \\
\text { number of } \\
\text { leukocytes, the } \\
\text { percentages of } \\
\text { leukocytes, } \\
\text { as well as the } \\
\text { concentrations of } \\
\text { immunoglobulins } \\
\text { and complement }\end{array}$ & 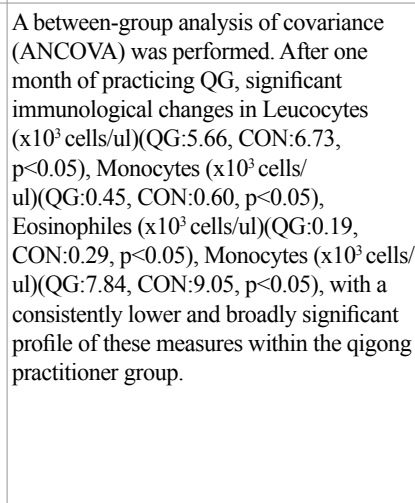 \\
\hline $\begin{array}{l}\text { Huang et al., } 2005 \\
\text { [117] (In Chinese) }\end{array}$ & CTs & 44 & China & $45-65$ & $\begin{array}{l}21 \mathrm{M}, \\
23 \mathrm{~F}\end{array}$ & none & BDJ & $\begin{array}{l}\text { Participants practice BDJ } \\
7 \text { times per week, each } \\
\text { time last for } 50 \text { minutes. } \\
\text { Last for } 10 \text { weeks. During } \\
\text { the intervention periods, } \\
\text { participants keep a normal } \\
\text { lifestyle. }\end{array}$ & $\begin{array}{l}\text { To investigate } \\
\text { effect BDJ on the } \\
\text { related indexes } \\
\text { of free radical } \\
\text { metabolism, } \\
\text { including } \\
\text { nitricoxide, } \\
\text { malondialdehyde } \\
\text { and superoxide } \\
\text { dismutase }\end{array}$ & $\begin{array}{l}\text { After } 10 \text { weeks of intervention, there } \\
\text { shows a trend of improving in each groups } \\
\text { of participants. } \\
\text { There's a significant reduce in } \\
\text { malondialdehyde level for elderly female } \\
\text { group. } 3.59 \pm 0.45 \text { vs. } 4.15 \pm 0.68 \mathrm{p}<0.05 \\
\text { There's a significant improvement in nitric } \\
\text { oxide level and superoxide dismutase level } \\
\text { for elderly male. } \\
\text { NO: } 558.374 \pm 243.91 \text { vs. } 471.13 \pm 168.12 \\
p<0.05 \\
\text { superoxide dismutase: } \\
1.75 \pm 0.17 \text { vs. } 1.49 \pm 0.22 \mathrm{p}<0.01\end{array}$ \\
\hline
\end{tabular}




\begin{tabular}{|c|c|c|c|c|c|c|c|c|c|c|}
\hline $\begin{array}{l}\text { Lu et al., } 2006 \\
{[118]}\end{array}$ & QED & 90 & Taiwan & $\begin{array}{l}\text { TCC: } 53.0 \\
\text { (41-71); WTK: } \\
\text { 58.5(48.0-70.0); } \\
\text { Control: } 56.5 \\
(32-72)\end{array}$ & $\begin{array}{l}\text { TCC: } \\
\text { 14M16F; } \\
\text { WTK: } \\
\text { 12M18F; } \\
\text { Control: } \\
\text { 7M23F }\end{array}$ & $\begin{array}{l}\text { TCC: } 2.0 \mathrm{yr} \\
\text { experience; } \\
\text { WTK: } \\
2.3 \mathrm{yr} \\
\text { experience; } \\
\text { Control: } \\
0 \mathrm{yr}\end{array}$ & WTK & $\begin{array}{l}\text { Participants were divided } \\
\text { into non-exercising control } \\
\text { (N=30), TaiChiChung } \\
\text { (TCC) practitioners (N=30) } \\
\text { and WaiTanKung (WTK) } \\
\text { practitioners (N=30). } \\
\text { TCC: } 40 \text { min in duration } \\
\text { (10 min warm up, } 20 \text { min } \\
\text { exercise, } 10 \text { min cool } \\
\text { down), WTK: } 40 \text { min in } \\
\text { duration ( } 5 \text { min warm up, } \\
30 \text { exercise, } 5 \text { min relaxing). } \\
\text { The resting standard 12- } \\
\text { lead ECG, arterial blood } \\
\text { pressure measurement were } \\
\text { performed on each subject } \\
\text { before TCC or WTK } \\
\text { with the subject lying } \\
\text { in supine position was } \\
\text { performed on each } \\
\text { subject before TCC or } \\
\text { WTK in standing position. } \\
\text { Measurements took place } 30 \\
\text { and } 60 \text { minutes after exercise }\end{array}$ & $\begin{array}{l}\text { To compare } \\
\text { the effects of } \\
\text { TCC and WTK } \\
\text { on autonomic } \\
\text { nervous system } \\
\text { modulation and on } \\
\text { hemodynamics } \\
\end{array}$ & 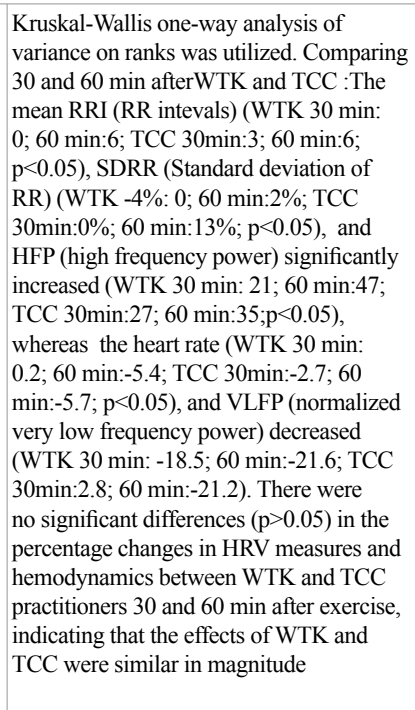 \\
\hline
\end{tabular}

'TC=total cholesterol, $\mathrm{TG}=$ triglyceride LDL-C=low-density lipoprotein cholesterol, HDL-C=high-density lipoprotein cholesterol

${ }^{2} \mathrm{TC}=$ total cholesterol, $\mathrm{TG}=$ triglyceride LDL-C=low-density lipoprotein cholesterol, HDL-C=high-density lipoprotein cholesterol, SOD=Superoxide dismutase,

GSH-Px=glutathione peroxidase, MDA=plasma malondialdehyde; YJJ: Yi-Jing-Jing

${ }^{3} \mathrm{TBIL}=$ total bilirubin,DBIL=direct bilirubin, $\mathrm{IBIL}=$ indirect bilirubin

due to the ineffectiveness of the type of Qigong. Apart from the various styles and types of Qigong, our review also shows that the effect of Qigong can be either measured specifically at the meditation state, or during the component of physical exercise. Although from this current review we can see that both components have shown biological or physiological effects, limited research to date has juxtapose measuring both components within the same study design. A recent randomized controlled trial reported that Baduanjin exercise, a popular form of Qigong, effectively reversed left ventricular remodeling in patients with post- Myocardial Infarction [63]. Future studies should examine the effectiveness of one form of Qigong to another, and further research is needed to more rigorously examine the better form of Qigong for specific quantifiable bio-physical effects.

While some subset of biofield devises, including those based on EEG heart rate variabilities that are widely used and employed in clinical settings, other devise modalities still have unclear clinical relevance. The interactions of biofield, defined as "an organizing principle for the dynamic information flow that regulates biological function and homeostasis', can affect and be affected by various biological, biochemical, cellular, and neurological across multiple levels of biology. As this review shows, given TCM posits that the disruption of energy flow is the cause of diseases, the harmonization of the flow of vital energy, or Qi, is posed as the solution to such ailments; in other words such interactions mainly focuses on the mechanical interactions. While current technological advances help us better assess the efficacy of devices, further research on Qi energy could benefit from the application of novel modalities with particular emphasis in mechanical or physical interactions [64].

Last, whereas many studies in this review have consistently suggested the significant physiological and biological effects of Qigong therapies, the broader question remains: what is the mechanical pathway behind such healing effects? Currently, biomedical researchers have stated that energy field therapies are effective because they project 'information' into tissues [65]. While researchers consider this an 
interesting hypothesis, it leaves many unanswered questions of why tissue repairs are not activated naturally. Why would it be necessary to trigger healing process with an external signal and not something that occurs from within? And what is the mechanism behind the signal triggering healing process? Although the answers posed here are beyond what this paper aimed to address, next steps of scientific inquiry is necessary to better understand the bio-physical and chemical pathways of Qigong healing process.

\section{Limitations}

Despite these significant findings, there are some limitations to the current state of methodological issues pertaining to Qigong research. First, small sample size makes it difficult to interpret results and raises questions in generalizability. For example, current publication on external qi on physical and biological systems frequently involves a single, or few qigong masters. Such situations may also introduce conflict of interests; participants should not be involved in the design of the study and should be blinded during the measurement. Second, there is a lack of sophisticated research design and compatible control groups undermine the results of many methods studies. Third, most Qigong practices may lack a facilitation program or manual to be successfully replicated. Given there is no generic form of Qigong, which calls to question how closely the type of Qigong used in these research trials resembles traditional forms, whether the cultural component of Qigong influences researchers and participants, and whether Qigong is treated just as a low-intensity exercise.

Furthermore, due to the lack of investigation in current literature, the role of culture or belief in Qigong practice remains central. In areas of biomedicine, cultural belief has been shown to impact compliance which could also influence health outcomes [66]. When investigating a practice or treatment such as Qigong which often explicitly incorporates non-biomedical beliefs about "energy," considering the influence of beliefs is necessary to examine which components may influence the outcome. Further, evidence shows that the concept of $Q i$, which does not have a biomedical analog, could very important among Qigong practitioners [67]. While their findings are impressive, most of these studies have methodological weaknesses. Moreover, it is not clear how much Chinese culture contributes to these outcomes or whether the benefits of qigong can be realized in an American population [68]. It is necessary to thoroughly examine how culturally relevant practices like Qigong may specifically relate to their health. Future studies should consider improving the conceptual framework on cultural believes in biomedical studies, and measures to better operationalize the potential impact of cultural beliefs in health outcomes.

\section{Future research directions}

In order to further understand the Qi measurement issues; there are multiple areas of research which should be addressed concerning study design, the complexities of Qigong, and the role of culture. It should be noted that CAM researchers have proposed a variety of directions for research pertaining to older adults which apply to Qigong research as well, including: understanding motivations for use or practice, safety concerns, longitudinal study design, larger sample size, including qualitative or ethnographic study design, and challenging the common health research approach of a biomedical framework [69]. Longitudinal, population-based studies should be conducted in community-dwelling settings to understand the current practice of and sociodemographic and health associations with Qigong. Although traditional doubleblind clinical trials may be difficult to apply to qigong study due to a lack of a compatible sham qigong, in reality, a reasonably large sample size with a compatible control may be crucial for examining such an alternative therapy. The next step should also include information about culturally relevant exercise behaviors with additional qualitative interviews to understand their practice of Qigong.

Furthermore, future studies in this area should not only focus on physical or chemical detectors, but also use more biological or life detectors to increase our understanding of the bio-information contained within qigong. Furthermore, future research needs to evaluate the effectiveness of different forms of Qigong and another mind-body exercise, particularly Tai Chi, a similar and less meditative exercise to Qigong, in order to ascertain the appropriateness of these exercises for persons with different functional abilities.

\section{Practice and policy implications}

Last, this review has implications for health providers and policymakers. As one of the five treatment principles in traditional Chinese medicine, Qigong exercise postulates balance and harmonization as the principle aim of a treatment [70]. Recent CAM research of older adults has called for further integration of nonbiomedical biomedical options for addressing certain health concerns [69]. Health providers should provide information to older adults about Qigong as exercise, especially since there is some evidence that Qigong practice lowers medical costs and visits [71]. Integrating Qigong classes into community exercise offerings may be able to address these issues of maintaining exercise in advancing age, especially for minority adults who desire culturally-specific group exercise activities [72].

\section{Conclusion}

In conclusion, the existing body of measurement research regarding Qi indicates that Qigong may be an effective way of improving health outcomes, including overall quality of life, psychological distress, and pain. Research methodology should rigorously evaluate Qigong versus other forms of mind-body exercise and whether cultural specificity and CAM beliefs affect health outcomes. Research scientists, health providers, and community leaders should work in concert to investigate and improve the physical and psychosocial health and health behaviors of minority populations through culturally appropriate and adaptable exercise like Qigong.

\section{References}

1. Liu X, Miller Y, Burton N, Brown W (2010) A preliminary study of the effects of Tai Chi and Qigong medical exercise on indicators of metabolic syndrome, glycaemic control, health-related quality of life, and psychological health in adults with elevated blood glucose. Br J Sports Med 44: 704-709. [Crossref]

2. Lu Z (1997) Scientific Qigong exploration: The Wonders and Mysteries of Qi. Amber Leaf Press, Malvern, PA.

3. Cohen K (1999) The way of Qigong: The art and science of Chinese energy healing. Ballantine Books, New York.

4. Oh B, Butow P, Mullan B, Hale A, Lee MS, et al. (2012) A critical review of the effects of medical Qigong on quality of life, immune function, and survival in cancer patients. Integr Cancer Ther 11: 101-110. [Crossref]

5. Chan CL, Wang CW, Ho RT, Ng SM, Chan JS, et al. (2012) A systematic review of the effectiveness of qigong exercise in supportive cancer care. Support Care Cancer 20: 1121-1133. [Crossref]

6. Klein PJ, Schneider R, Rhoads CJ3 (2016) Qigong in cancer care: a systematic review and construct analysis of effective Qigong therapy. Support Care Cancer. [Crossref]

7. Tao WW, Jiang H, Tao XM, Jiang P, Sha LY, et al. (2016) Effects of Acupuncture, Tuina, Tai Chi, Qigong, and Traditional Chinese Medicine Five-Element Music Therapy on Symptom Management and Quality of Life for Cancer Patients: A Meta-Analysis. $J$ Pain Symptom Manage 51: 728-747. [Crossref] 
8. Ng B, Tsang H, Ng B, So C (2014) Traditional Chinese exercises for pulmorary rehabilitation: Evidence from a systematic review. Journal of Cardiopulmonary Regabilitation and Prevention 34: 367-377. [Crossref]

9. Chan CL, Wang CW, Ho RT, Ho AH, Ziea ET, et al. (2012) A systematic review of the effectiveness of qigong exercise in cardiac rehabilitation. Am J Chin Med 40: 255-267. [Crossref]

10. Lee MS, Pittler MH, Guo R, Ernst E (2007) Qigong for hypertension: a systematic review of randomized clinical trials. J Hypertens 25: 1525-1532. [Crossref]

11. Xiong X, Wang P, Li X, Zhang Y (2015) Qigong for hypertension: a systematic review. Medicine (Baltimore) 94: e352. [Crossref]

12. Guo X, Zhou B, Nishimura T, Teramukai S, Fukushima M (2008) Clinical effect of qigong practice on essential hypertension: a meta-analysis of randomized controlled trials. J Altern Complement Med 14: 27-37. [Crossref]

13. Wang CW, Ng SM, Ho RT, Ziea ET, Wong VC, et al. (2012) The effect of qigong exercise on immunity and infections: a systematic review of controlled trials. $A m J$ Chin Med 40: 1143-1156. [Crossref]

14. Lee MS, Ernst E (2009) Qigong for movement disorders: A systematic review. Mov Disord 24: 301-303. [Crossref]

15. Yang Y, Qiu WQ, Hao YL, Lv ZY, Jiao SJ, et al. (2015) The efficacy of traditional Chinese Medical Exercise for Parkinson's disease: a systematic review and metaanalysis. PLoS One 10: e0122469. [Crossref]

16. Chan CL, Wang CW, Ho RT, Ng SM, Ziea ET, et al. (2012) Qigong exercise for the treatment of fibromyalgia: a systematic review of randomized controlled trials. J Altern Complement Med 18: 641-646. [Crossref]

17. Lee MS, Chen KW, Choi TY, Ernst E (2009) Qigong for type 2 diabetes care: a systematic review. Complement Ther Med 17: 236-242. [Crossref]

18. Lee MS, Pittler MH, Ernst E (2009) Internal qigong for pain conditions: a systematic review. J Pain 10: 1121-1127. [Crossref]

19. Oh B, Choi SM, Inamori A, Rosenthal D, Yeung A (2013) Effects of qigong on depression: a systemic review. Evid Based Complement Alternat Med 2013: 134737. [Crossref]

20. Wang CW, Chan CH, Ho RT, Chan JS, Ng SM, et al. (2014) Managing stress and anxiety through qigong exercise in healthy adults: a systematic review and meta-analysis of randomized controlled trials. BMC Complement Altern Med 14: 8. [Crossref]

21. Chen KW (2004) An analytic review of studies on measuring effects of external QI in China. Altern Ther Health Med 10: 38-50. [Crossref]

22. Lin Z, Chen K (2002) Exploratory studies of external Qi in China. Journal of International Society of Life Information Sciences 20: 457-461.

23. Chen KW (2004) An analytic review of studies on measuring effects of external QI in China. Altern Ther Health Med 10: 38-50. [Crossref]

24. Hintz KJ, Yount GL, Kadar I, Schwartz G, Hammerschlag R, et al. (2003) Bioenergy definitions and research guidelines. Altern Ther Health Med 9: A13-30. [Crossref]

25. Mayer M (1999) Qigong and hypertension: a critique of research. J Altern Complement Med 5: 371-382. [Crossref]

26. Chen K (2015) Methodological challenges and research design in research study of qigong therapies. In: Methodologies for Effective Assessing Complementary and Alternative Medicine (CAM): Research Tools and Techniques: Singing Dragon Pp. 228-248.

27. Lo S (2007) Evidence and mechanism of external Qi in chinese medicine. Medical Acupuncture 19: 2001-2009.

28. Matos LC, Sousa CM, GonÃ ̧alves M, Gabriel J, Machado J, et al. (2015) Qigong as a Traditional Vegetative Biofeedback Therapy: Long-Term Conditioning of Physiological Mind-Body Effects. Biomed Res Int: 31789. [Crossref]

29. Litscher G, Wenzel G, Niederwieser G, Schwarz G (2001) Effects of QiGong on brain function. Neurol Res 23: 501-505. [Crossref]

30. Matos LC, Sousa CM, GonÃ ̧alves M, Gabriel J, Machado J, et al. (2015) Qigong as a Traditional Vegetative Biofeedback Therapy: Long-Term Conditioning of Physiological Mind-Body Effects. Biomed Res Int 2015: 531789. [Crossref]

31. Zimmerman J (1989) Zimmerman J: Laying-on-of-hands and therapeutic touch: a testable theory, BEMI currents. J Bio-Electro-Magnet Ins 1989: 2-8.

32. Seto A, Kusaka C, Nakazato S, Huang WR, Sato T, et al. (1992) Detection of extraordinary large bio-magnetic field strength from human hand during external Qi emission. Acupunct Electrother Res 17: 75-94.[Crossref]

33. Hisamitsu T, Seto A, Nakazato S, Yamamoto T, Aung SK (1996) Emission of extremely strong magnetic fields from the head and whole body during oriental breathing exercises. Acupunct Electrother Res 21: 219-227. [Crossref]

34. Yu WL, Li XQ, Tang WJ, Li Y, Weng XC, et al. (2007) fMRI study of pain reaction in the brain under state of "Qigong". Am J Chin Med 35: 937-945. [Crossref]

35. Chan AS, Cheung MC, Chan YL, Yeung DK, Lam W (2006) Bilateral frontal activation associated with cutaneous stimulation of elixir field: an FMRI study. Am J Chin Med 34: 207-216. [Crossref]

36. Litscher G, Wenzel G, Niederwieser G, Schwarz G (2001) Effects of QiGong on brain function. Neurol Res 23: 501-505. [Crossref]

37. Faber PL, Lehmann D, Tei S, Tsujiuchi T, Kumano H, et al. (2012) EEG source imaging during two Qigong meditations. Cogn Process 13: 255-265. [Crossref]

38.

Qin Z, Jin Y, Lin S, Hermanowicz NS (2009) A forty-five year follow-up EEG study of Qigong practice. Int J Neurosci 119: 538-552. [Crossref]

39. Baldwin AL, Hammerschlag R2 (2014) Biofield-based therapies: a systematic review of physiological effects on practitioners during healing. Explore (NY) 10: 150-161. [Crossref]

40. Zhang W, Zheng R, Zhang B, Yu W, Shen X (1993) An observation on flash evoked cortical potentials and Qigong meditation. Am J Chin Med 21: 243-249. [Crossref]

41. Liu GL, Cui RQ, Li GZ, Huang CM (1990) Changes in brainstem and cortical auditory potentials during Qi-Gong meditation. Am J Chin Med 18: 95-103. [Crossref]

42. Kuan SC, Chen KM, Wang C (2012) Effectiveness of Qigong in promoting the health of wheelchair-bound older adults in long-term care facilities. Biol Res Nurs 14: 139146. [Crossref]

43. Lu WA, Kuo CD (2003) The effect of Tai Chi Chuan on the autonomic nervous modulation in older persons. Med Sci Sports Exerc 35: 1972-1976. [Crossref]

44. Chang MY (2015) Qigong Effects on Heart Rate Variability and Peripheral Vasomotor Responses. West J Nurs Res 37: 1383-1403. [Crossref]

45. Jones BM (2001) Changes in cytokine production in healthy subjects practicing Guolin Qigong : a pilot study. BMC Complement Altern Med 1: 8. [Crossref]

46. Lee MS, Kim BG, Huh HJ, Ryu H, Lee HS, et al. (2000) Effect of Qi-training on blood pressure, heart rate and respiration rate. Clin Physiol 20: 173-176. [Crossref]

47. Lee MS, Rim YH, Kang CW (2004) Effects of external qi-therapy on emotions, electroencephalograms, and plasma cortisol. Int J Neurosci 114: 1493-1502. [Crossref]

48. Yeh ML, Lee TI, Chen HH, Chao TY (2006) The influences of Chan-Chuang qigong therapy on complete blood cell counts in breast cancer patients treated with chemotherapy. Cancer Nurs 29: 149-155. [Crossref]

49. Lin H (2013) Effects of Wuqinxi on senior patients with hypertension. Chinese Journal of Geriatrics 2013: 33.

50. Li C (2013) Effect of health qigong and new skills on the middle and old aged people's blood lipid. Journal of Chengdu Sport University: 39.

51. Chen, Chen (2015) Effect of Taichi and Qigong on blood lipid and life quality of middle aged and elderly people. Chinese Journal of Geriatrics: 35.

52. Liu X, Miller YD, Burton NW, Brown WJ (2010) A preliminary study of the effects of Tai Chi and Qigong medical exercise on indicators of metabolic syndrome, glycaemic control, health-related quality of life, and psychological health in adults with elevated blood glucose. Br J Sports Med 44: 704-709. [Crossref]

53. Sun GC, Lovejoy JC, Gillham S, Putiri A, Sasagawa M, et al. (2010) Effects of Qigong on glucose control in type 2 diabetes: a randomized controlled pilot study. Diabetes Care 33: e8. [Crossref]

54. Manzaneque JM, Vera FM, Rodriguez FM, Garcia GJ, Leyva L, et al. (2009) Serum cytokines, mood and sleep after a qigong program: is qigong an effective psychobiological tool? J Health Psychol 14: 60-67. [Crossref]

55. Ryu H, Lee HS, Shin YS, Chung SM, Lee MS, et al. (1996) Acute effect of qigong training on stress hormonal levels in man. Am J Chin Med 24: 193-198. [Crossref]

56. Weidermann M, Smith J, Gray A, Pyne D, Braddon M, et al. (1994) Exercise and neutrophil activity: A possible neuroendocrine connection. In: PsychoimmunologyL CNS- Immune Interactions: CRS Press. Pp. 31-50. 
57. Lee MS, Kim MK, Ryu H (2005) Qi-training (qigong) enhanced immune functions: what is the underlying mechanism? Int J Neurosci 115: 1099-1104. [Crossref]

58. Ryu H, Lee MS, Jeong SM, Lee JH, Kang CW, et al. (2000) Modulation of neuroendocrinological function by psychosomatic training: acute effect of ChunDoSunBup Qi-training on growth hormone, insulin-like growth factor (IGF)-I, and insulin-like growth factor binding protein (IGFBP)-3 in men. Psychoneuroendocrinology 25: 439-451.

59. Lee MS, Huh HJ, Jeong SM, Lee HS, Ryu H, et al. (2003) Effects of Qigong on immune cells. Am J Chin Med 31: 327-335. [Crossref]

60. Manzaneque JM, Vera FM, Maldonado EF, Carranque G, Cubero VM, et al. (2004) Assessment of immunological parameters following a qigong training program. Med Sci Monit 10: CR264-270. [Crossref]

61. Yang Y, Verkuilen J, Rosengren KS, Mariani RA, Reed M, et al. (2007) Effects of a Taiji and Qigong intervention on the antibody response to influenza vaccine in older adults. Am J Chin Med 35: 597-607. [Crossref]

62. Liu X, Miller YD, Burton NW, Brown WJ (2010) A preliminary study of the effects of Tai Chi and Qigong medical exercise on indicators of metabolic syndrome, glycaemic control, health-related quality of life, and psychological health in adults with elevated blood glucose. Br J Sports Med 44: 704-709. [Crossref]

63. Mao S, Zhang X, Shao B, Hu X, Hu Y, et al. Baduanjin Exercise Prevents postMyocardial Infarction Left Ventricular Remodeling (BE-PREMIER trial): Design and Rationale of a Pragmatic Randomized Controlled Trial. Cardiovasc Drugs Ther

64. Muehsam D, Chevalier G, Barsotti T, Gurfein BT4 (2015) An Overview of Biofield Devices. Glob Adv Health Med 4: 42-51. [Crossref]

65. Oschman J (2000) Energy Medicine: The Scientific Basis: Elsevier, USA.

66. Ross S, Walker A, MacLeod MJ (2004) Patient compliance in hypertension: role of illness perceptions and treatment beliefs. J Hum Hypertens 18: 607-613. [Crossref]

67. Jouper J, HassmÃ $\mathrm{C}$ P (2009) Exercise intention, age and stress predict increased qigong exercise adherence. J Bodyw Mov Ther 13: 205-211. [Crossref]

68. Dong X, Bergren SM, Chang ES (2015) Traditional Chinese Medicine Use and Health in Community-Dwelling Chinese-American Older Adults in Chicago. J Am Geriatr Soc 63: 2588-2595. [Crossref]

69. Willison KD, Andrews GJ (2004) Complementary medicine and older people: pas research and future directions. Complement Ther Nurs Midwifery 10: 80-91. [Crossref]

70. Eisenhardt S, Fleckenstein J (2016) Traditional Chinese medicine valuably augments therapeutic options in the treatment of climacteric syndrome. Arch Gynecol Obstet. [Crossref]

71. Yan X, Shen H, Loh C, Shao J, Yang Y, et al. (2013) A longitudinal study about the effect of practicing Yan Xin Qigong on medical care cost with medical claims data. Int $J$ Econ Res 10: 391-403.[Crossref]

72. Belza B, Walwick J, Shiu-Thornton S, Schwartz S, Taylor M, et al. (2004) Older adult perspectives on physical activity and exercise: voices from multiple cultures. Prev Chronic Dis 1: A09. [Crossref]

73. Shin H, Kim J, Soh K (2003) Investigation of Anomalous Bio-Magnetic Fields from Human Hand During Qi Emission. Journal of International Society of Life Information Science 21: 42-49.

74. Ho FM, Ding HY, Chyau CC, Kuo HY, Yen MT, et al. (2011) To accomplish preliminary Qigong simulation state by acupuncture. Zhong Xi Yi Jie He Xue Bao 9: 1094-1100. [Crossref]

75. Fong D, Hung T, Huang Y (2004) The effects of qigong on relaxation and emotion. Taiwan Sports Psychology 5: 19-42.

76. Lee MS, Bae BH, Ryu H, Sohn JH, Kim SY, et al. (1997) Changes in alpha wave and state anxiety during ChunDoSunBup Qi-training in trainees with open eyes. Am J Chin Med 25: 289-299. [Crossref]

77. Kuo T, Ho F, Lin C (2003) Physiological changes associated with Neiyang Qigong. Journal of Health Sciences 49: 278-284.

78. Wirth DP, Cram JR, Chang RJ (1997) Multisite electromyographic analysis of therapeutic touch and qigong therapy. J Altern Complement Med 3: 109-118. [Crossref]

79. Chang MY (2015) Qigong Effects on Heart Rate Variability and Peripheral Vasomotor Responses. West J Nurs Res 37: 1383-1403. [Crossref]

80. Zhang (2006) Research and health care qigong on Cardiac and cerebral vessal of middle and elder people. China Sport Science and Technology 42: 98-101.
81. Lee MS, Kim MK, Lee YH (2005) Effects of Qi-therapy (external Qigong) on cardiac autonomic tone: a randomized placebo controlled study. Int J Neurosci 115: 1345-1350. [Crossref]

82. Lim YA, Boone T, Flarity JR, Thompson WR (1993) Effects of qigong on cardiorespiratory changes: a preliminary study. Am J Chin Med 21: 1-6. [Crossref]

83. Sun FL, Yan YA (1992) [Effects of various qigong breathing pattern on variability of heart rate]. Zhongguo Zhong Xi Yi Jie He Za Zhi 12: 527-530, 516.[Crossref]

84. Lan C, Chou SW, Chen SY, Lai JS, Wong MK (2004) The aerobic capacity and ventilatory efficiency during exercise in Qigong and Tai Chi Chuan practitioners. Am J Chin Med 32: 141-150. [Crossref]

85. Zeng (2013) Effect of Relaxation Qigong on hypertension of the elderly patients Chinese Journal of Social Medicine 2013: 30.

86. Huang L (2013) Effects of Wuqinxi on senior patients with hypertension. Chinese Journal of Geriatrics 2013: 33.

87. Lee M, Choi E, Chung H (2003) Effects of Qigong on blood pressure, blood pressure determinants and ventilatory function in middle-aged patients with essential hypertension. Am J Chin Med 31: 489-497. [Crossref]

88. Cheung BM, Lo JL, Fong DY, Chan MY, Wong SH, et al. (2005) Randomised controlled trial of qigong in the treatment of mild essential hypertension. J Hum Hypertens 19 : 697-704. [Crossref]

89. Lee MS, Lim HJ, Lee MS (2004) Impact of qigong exercise on self-efficacy and other cognitive perceptual variables in patients with essential hypertension. $J$ Altern Complement Med 10: 675-680. [Crossref]

90. Sun (2008) Influence of fitness Qigong (Baduanjin) on blood lipid and physioloigca function of the elder male people. China Sport Science and Technology 44: 81-84.

91. Lee MS, Lee MS, Kim HJ, Choi ES (2004) Effects of qigong on blood pressure, highdensity lipoprotein cholesterol and other lipid levels in essential hypertension patients. Int J Neurosci 114: 777-786. [Crossref]

92. Vera FM, Manzaneque JM, Maldonado EF, Carranque GA, Cubero VM, et al. (2007) Biochemical changes after a qigong program: lipids, serum enzymes, urea, and creatinine in healthy subjects. Med Sci Monit 13: CR560-566. [Crossref]

93. Miao F, Liu X, Wang X (2009) Effects of fitness qigong baduanjin on plasma lipid and lipoprotein metabolism of patients with hyperlipidemia. Journal of Shandong Institute of Physical Education and Sports 2009.

94. Liang (2014) Effect of Baduanjin on blood pressure and blood lipid of patients with essential hypertension. Henan Traditional Chinese Medicine 2014: 34.

95. Jin L (2010) Effect of fitness Qigong (Yijinjing) on blood lipid and free radical metabolism of the elder women. China Journal of Traditional Chinese Medicine and Pharmacy 2010: 25 .

96. Youngwanichsetha S, Phumdoung S, Ingkathawornwong T (2013) The effects of tai chi qigong exercise on plasma glucose levels and health status of postpartum Thai women with type 2 diabetes. Focus on Alrernative and Complementary Therapies 2013;18:182-7.

97. Iwao M, Kajiyama S, Mori H, Oogaki K (1999) Effects of qigong walking on diabetic patients: a pilot study. J Altern Complement Med 5: 353-358. [Crossref]

98. Tao Y (2015) Effects of BaDuanJin exercise on Bilirubin in type 2 diabetes patients Guiding Journal of Traditional Chinese Medicine and Pharmacy 2015: 21.

99. Oh B, Butow P, Mullan B, Clarke S, Beale P, et al. (2010) Impact of medical Qigong on quality of life, fatigue, mood and inflammation in cancer patients: a randomized controlled trial. Ann Oncol 21: 608-614. [Crossref]

100. Oh B, Butow P, Mullan B, Clarke S (2008) Medical Qigong for cancer patients: pilot study of impact on quality of life, side effects of treatment and inflammation. $\mathrm{Am} \mathrm{J}$ Chin Med 36: 459-472. [Crossref]

101. Chan ES, Koh D, Teo YC, Hj Tamin R, Lim A, et al. (2013) Biochemical and psychometric evaluation of Self-Healing Qigong as a stress reduction tool among first year nursing and midwifery students. Complement Ther Clin Pract 19: 179-183. [Crossref]

102. Sousa CM, Goncalves M, Machado J, Efferth T, Greten T, et al. (2012) Effects of qigong on performance-related anxiety and physiological stress functions in transverse flute music schoolchildren: a feasibility study. Zhong Xi Yi Jie He Xue Bao 10: 858-68.

103. Chow Y, Siu A (2012) The effects of qigong on reducing stress and anxiety and enhacing body-mind well-being. Mindfulness 3: 51-59. 
104. Bayat-Movahed S, Shayesteh Y, Mehrizi H, Rezayi S, Bamdad K, et al. (2008) Effects of Qigong exercises on 3 different parameters of human saliva. Chin J Integr Med 14: 262-266. [Crossref]

105. Wu Y (2008) Effects of exercising building up Qigong Quqinxi on middle aged and old peopls' NK cell activity. Journal of Shanghai University of Sport 2008: 32.

106. Vera FM, Manzaneque JM, Rodriguez FM, Bendayan R, Fernandez N, et al. (2015) Acute effects on the counts of innate and adaptive immune response cells after 1 month of taoist qigong practice. Int J Behav Med 23: 198-203. [Crossref]

107. Lee M, Kang CW, Ryu H (2005) Acute effect of qi-training on natural killer cell subsets and cytotoxic activity. Int J Neurosci 115: 285-297. [Crossref]

108. Jung MJ, Shin BC, Kim YS, Shin YI, Lee MS (2006) Is there any difference in the effects of Qi therapy (external Qigong) with and without touching? A pilot study. Int J Neurosci 116: 1055-1064. [Crossref]

109. Lee MS, Kang CW, Ryu H, Kim JD, Chung HT (1999) Effects of ChunDoSunBup Qi-training on growth hormone, insulin-like growth factor-I, and testosterone in young and elderly subjects. Am J Chin Med 27: 167-175. [Crossref]

110. Ryu H, Jun CD, Lee BS, Choi BM, Kim HM, et al. (1995) Effect of qigong training on proportions of T lymphocyte subsets in human peripheral blood. Am J Chin Med 23: 27-36. [Crossref]

111. Yao BS (1989) [A preliminary study on the changes of T-cell subsets in patients with aplastic anemia treated with qigong]. Zhong Xi Yi Jie He Za Zhi 9: 341-3, 324. [Crossref]
112. Ryu H, Mo H, Mo G (1995) Delayed cutaneous hypersensitivity reactions in Qigong (Chun Do Sun Bup) trainees by multisite cell mediated immunity. American Journal of Chinese Medicine 2: 139-144.

113. Sang Q (2011) Effect of "wuqinxi" exercise on antioxidant status, intestine Bacillus acidophilus, lactobacillus casei and Bacillus bifidus in obese old people. Journal of Medicinal Plants Research 5: 4225-4447.

114. Kim E, Woon J (2013) Impact of Qi-gong for mental and physical training on the body composition and aging-related hormone of middle-aged women. Exercise Science 22: 239-247.

115. Lee MS, Kang CW, Ryu H, Moon SR (2004) Endocrine and immune effects of Qitraining. Int J Neurosci 114: 529-537. [Crossref]

116. Lee MS, Jeong SM, Kim YK, Park KW, Lee MS, et al. Qi-training enhances respiratory burst function and adhesive capacity of neutrophis in young adults: A prelimirary study. Am J Chin Med 31: 141-148. [Crossref]

117. Chang H (2005) Influence of body building qigong and eight-sectioned brocade on the metabolism of nitric oxide, malondialdehyde and superoxide dismutase in middleaged and elderly people of different gender. Chinese Journal of Clinical Rehabilitation 9.

118. Lu WA, Kuo CD (2006) Comparison of the effects of Tai Chi Chuan and Wai Tan Kung exercises on autonomic nervous system modulation and on hemodynamics in elder adults. Am J Chin Med 34: 959-968. [Crossref]

119. Lu WA, Kuo CD (2003) The effect of wai tan kung on autonomic nervous modulation in the elderly. J Biomed Sci 10: 697-705. [Crossref]

Copyright: (C2016 Dong X. This is an open-access article distributed under the terms of the Creative Commons Attribution License, which permits unrestricted use, distribution, and reproduction in any medium, provided the original author and source are credited. 